\title{
Actors behaving badly: exploring the modelling of non- optimal behaviour in energy transitions
}

Accepted Manuscript: $22^{\text {nd }}$ January 2017, Energy Strategy Reviews Volume 15, Pages 57-71

doi:10.1016/j.esr.2017.01.002

Francis G. N. Li , francis.li@ucl.ac.uk

a University College London, UCL Energy Institute, Central House, 14 Upper Woburn

Place, London, WC $1 \mathrm{H}$ oNN, United Kingdom

(C) 2017. This manuscript version is made available under the CC-BY-NC-ND 4.0 license http://creativecommons.org/licenses/by-nc-nd/4.0/

\begin{abstract}
There are real political and social barriers to climate mitigation that arise from multiactor dynamics and micro-economic decisions. Exploratory analysis that captures key uncertainties in the energy system, including behaviour, is crucial for policy design aimed at achieving ambitious greenhouse gas (GHG) mitigation targets. This paper explores the case for developing policy assessments that include non-optimal behaviour in energy systems modelling. A stochastic system dynamic model of the energy system that features multiple actors with differentiated behaviours is used to investigate energy transition pathways that deviate from strict economic rationality. The results illustrate the risks of basing GHG reduction strategies on analysis that overlooks key insights into decision making from fields such as behavioural economics and political science.
\end{abstract}

\section{Keywords}

Energy systems modeling; climate policy; decarbonization; behavioral economics; uncertainty;

\section{Highlights}

- Dynamic stochastic model of energy transitions used to explore actor behaviour

- Uncertainty analysis explores impact of sub-optimal actor choices and policies

- Behaviour could be as significant as the techno-economic drivers of transitions

- Climate targets difficult to achieve without idealised assumptions about behaviour

- Energy systems modelling must expand consideration of socio-political factors 


\subsection{The case for exploratory analysis of climate mitigation policies}

The 2015 Paris Agreement sets the stage for long term global reductions in greenhouse gas (GHG) emissions before the end of the century [1]. While there remain doubts over the cumulative level of ambition implied by current national pledges ([2] and [3]), the apportioning of the remaining global carbon budget [4], and whether or not $1.5^{\circ} \mathrm{C}$ or $2^{\circ} \mathrm{C}$ stabilisation will be sufficient to avoid "dangerous" anthropogenic warming ([5], [6] and [7]), many nations are nevertheless striving to explore pathways to deep decarbonisation ([8] and [9]). The "ratchet" mechanism in the Paris Agreement that requires signatories to periodically update their pledges for GHG mitigation means that there is likely to continue to be a long term focus on energy systems analysis and energy transition pathways.

Quantitative formal models of energy systems play a central role in this endeavour by providing an exploratory framework for thinking about the future, and developing the evidence base for long term policy decisions [10]. Energy system models used for decarbonisation pathway analysis operate at multiple scales, with global models used for integrated assessment of climate impacts [11], national models used for exploring domestic trajectories towards low carbon futures [12], and sectoral models used to explore detailed technological transitions in key end-use sectors such as power, transport and buildings [13]. Reviews by Jebaraj and Iniyan [14], Bhattacharyya and Timilsina [15], and Pfenninger et al. [16] can give the reader an overview of many common types of energy models used in policy analysis.

When discussing the use of models for decision making, it is useful to reflect on the work of Börjeson et al. [17] who distinguish between predictive, explorative and normative analysis. The complexity of assessing long term (i.e. multi-decadal) transitions in energy systems precludes the use of quantitative models for predictive (what will happen?) purposes, especially given that future energy transitions are subject to conditions of deep uncertainty [18]. Energy systems models therefore tend to be used for either normative analysis, to determine how specific targets can be reached, or explorative analysis that aims to map out the landscape of plausible futures.

Deep decarbonisation analysis at the national scale (e.g. as demonstrated for countries such as the United States [19], the United Kingdom [20], or Portugal [21]) is likely to become a key focus for the modelling community in the future as individual countries review their Paris Agreement commitments. Quantitative analysis in support of strategic decarbonisation planning is carried out using a variety of techniques, with the classic distinction being between macroeconomically complete top-down models, technology rich bottom-up models, and hybrids (see [22] and [9]). Energy system optimisation models (ESOMs) are a popular class of bottom-up models that explore dynamic trade-offs between technology and resources. Examples of ESOMs in widespread use include OSeMOSYS [23], MARKAL [24], and TIMES [25]. Such models are often subject to several common critiques.

Mathematically optimal solutions are often fragile to relatively small perturbations in the objective function, with the result that large changes in what could be interpreted as the "best" course of action can sometimes be found within a relatively small range 
of costs (see [26] and [27]). It has been suggested that over-reliance on costoptimisation risks leading to overly deterministic analysis that investigates only a narrow range of possible futures [28], and that heavily constrained model runs might simply be reflecting the biases (conscious or otherwise) of the model operator [29]. It is also argued that ESOMs with perfect foresight can lead policymakers to underestimate the challenge of using policy instruments to drive energy transitions, both because technology switching (if not constrained by other factors) occurs rapidly in the models and because costs are often the only modelled driver behind technology selection [30]. Ex post analysis of past scenario studies based on cost-optimisation analysis sometimes finds that nearly all real world developments have occurred outside of the previously modelled range of outcomes [31]. There is therefore a material requirement for new approaches to energy systems analysis that attempts a broader consideration of uncertainties [32].

The strong and active research community around energy systems modelling is making a number of parallel efforts to respond to these challenges. Modellers continue to develop techniques to expand the consideration of uncertainty in models. For example, approaches for understanding parametric uncertainties (e.g. by using Monte Carlo analysis [33]) and structural uncertainties (e.g. through implementing Modelling-to-Generate Alternatives approaches [34]) in models are becoming more widespread, as are multi-model comparison exercises [35]. Attempts to improve the representation of decision making include the development of myopic optimisation models [36] and models that employ stochastic programming and robust optimisation techniques [37]. Finally, there are efforts to improve the representation of actor behaviour in energy systems models. While it has long been typical practice to vary hurdle rates in ESOMs to explore time preference variation, models that account for a wider spectrum of behavioural parameters, such as heterogeneous choice behaviour, are becoming increasingly common [13].

\subsection{Behavioural complexity in energy modelling}

This paper focuses primarily on exploring the influence of non-optimal actor behaviour on long term decarbonisation pathways, as part of wider efforts to better address key uncertainties in energy systems analysis. That key stakeholders and individuals do not always exhibit purely cost optimising behaviour has been empirically observed for decades in energy policy. For example, rational economic analysis indicates that building energy efficiency measures are a "low hanging fruit" that should be rapidly adopted due to their cost-effective contribution to GHG mitigation, fuel poverty reduction, and energy security objectives. However, non-cost barriers to the widespread adoption of energy efficiency measures have historically prevented uptake to the levels expected by policymakers (e.g. [38] and [39]), in a phenomenon often termed "the energy efficiency gap" ([40] and [41]).

Failure or under-achievement in energy efficiency programmes is unfortunately common, with the collapse of the UK Government's flagship thermal improvement programme, the "Green Deal" being a recent prominent example [42]. During its short lifespan, the scheme achieved penetration rates far below anticipated levels and was abruptly cancelled with no replacement policy in place. A post-mortem report by the UK National Audit Office (NAO) linked the spectacular failure of the 
programme directly to poor policy design, which did not account for key behavioural factors in the consumer analysis and which ultimately "did not persuade householders that energy efficiency measures are worth paying for" [43].

Clearly, behavioural uncertainties cannot be safely ignored in policy design. Analysis shows that achieving deep decarbonisation is likely to require GHG reductions across the economy [8], including not only changes to energy generation but also in end-use demand sectors such as industry, buildings and transport. The level of agency that policymakers possess to influence transitions will vary by sector. In some countries, energy generation and other large industries may be state-owned or strongly regulated, giving the government powerful levers to direct investment in low carbon alternatives to fossil fuels. However, in all but the most repressive regimes, governments often have comparatively little influence over individual choices made by private citizens about what products they choose to purchase and use in their daily lives. This introduces significant uncertainties into decarbonisation pathways that are related to consumer behaviour in areas such as homes (e.g. building heating) and personal mobility (particularly road transport).

These uncertainties are often difficult to capture explicitly or remain underexplored in much energy systems analysis. It is typical for energy economy models to employ mathematical formulations based on cost optimisation, representing the allocation of resources on the basis of a single social planning agent who acts with perfect foresight. This omnipotent actor has no direct counterpart in reality, and acts as a representative proxy for high levels of collaboration, forward planning, and information exchange between different countries (at the global level) and economic sectors (at the national scale). This abstraction is not a barrier to the use of such tools for identifying cost-optimal pathways to normative futures, but does pose particular challenges when models are used in a more exploratory fashion to understand the range of possible futures that might transpire. For discussion purposes, we can further disaggregate behavioural uncertainties into:

i. The dynamics of decision making between actors and institutions, and;

ii. Micro-economic decision making by individual actors

\subsubsection{Behavioural dynamics between actors and institutions}

Historical analysis of past energy transitions shows that socio-technical change is often driven by politics and the power gradients between key stakeholders that supported different technologies or infrastructures. Useful examples can be found in a variety of sources, such as the work of Fouquet and Pearson [44], Sovacool [45], Fouquet [46], and Wilson and Grübler [47]. Historically, transformative changes in energy have only taken place relatively slowly, over multi-decade timescales [48], in contrast to the rapid transitions often observed in models. Real-world decision making occurs between multiple parties against a shifting set of political, economic and social priorities. This results in an environment where poorly coordinated policies, policies that directly oppose one another, or policies that are implemented in law but not enforced in practice can and do exist simultaneously. This leads to a policy environment that is sometimes characterised as being of a "second-best" nature ([49] and [50]), in contrast to the idealised "first-best" policymaking often found in models. Modellers themselves often acknowledge that the degree of coordination that needs 
to be assumed in order to represent rapid transitions towards a climate stabilised future might prove to be "highly unlikely" [51] and that efforts to represent delays, inertia or imperfections in transition governance are needed.

\subsubsection{Micro-economic behaviour}

As well as addressing the uncertainties related to the politics and governance dynamics of group decision making, another area for improving behavioural realism in energy modelling lies in the representation of individual actor choices. Energy models often rely on highly abstracted representations of individual choice at the micro-economic level. The dominant theoretical paradigm is to assume that investment behaviour will follow a pattern of rational choice and utility maximisation [52]. Thus, the rapid adoption of technological alternatives to fossil fuels is often observed in models when their costs fall below a certain inflection point. However, a wide body of evidence points towards real-world micro-economic decisions being more complex than a purely price-driven framework might suggest.

For example, it has been found that while prices are important determinants of purchasing behaviour, individual decisions are also strongly affected by social norms and customs (e.g. [53], [54] and [55]). Individuals often make choices that are influenced by non-price factors such as aesthetics, branding, or perceived reliability [56], and also act under conditions of bounded rationality without the time to exhaustively compare every possible option open to them ([57]and [58]). Finally, the desire for purchases to consciously reflect individual values in consumer society may also play a strong role in determining choices [59]. In summary, not only are different actors and institutions in the energy system likely to interact in a complex fashion, with different objectives and time horizons for making decisions, but costs will almost certainly not be the only factor influencing their future choices.

\subsection{Towards an improved representation of actors and behaviour in energy modelling}

Clearly, the rational choice basis for energy economic modelling is an abstraction that may have its shortcomings for exploratory, as opposed to normative, analysis. An improved representation of behaviour ([60] and [61]) and more explicit representation of actors and institutions ([62] and [63]) have both been argued to be important elements in improving the utility of energy models for policymaking. A number of energy economy models have been demonstrated with some degree of heterogeneous behaviour, including GCAM [64], IMAGE/TIMER [65], MESSAGETransport [66], TIMES [67], CIMS [68], and IMACLIM [69], but heterogeneous choice is still the exception rather than the rule in most model studies. The roles of actors and institutions tend to be mostly represented by discrete scenarios rather than endogenously represented in models. There appear to be a number of promising agent-based tools in development that could be applied for exploring decarbonisation pathways for climate stabilisation (e.g. [70] and [71]) but most published examples deal with sub-sectors of the energy economy and agent-based approaches have yet to scale fully to whole system analysis [72]. 
This paper aims to investigate the impact of actor behaviour on transitions to a low carbon future using BLUE, an energy model for the United Kingdom (UK) that incorporates multiple actors with differentiated micro-economic behavioural parameters. The UK is by no means unique amongst nations in having set out concrete ambitions to decarbonise its economy. It does however, remain an interesting case study, because of the presence of a long term, legally binding domestic emissions target for 2050 (the Climate Change Act 2008, see [73]) that enjoys broad cross party political support and forms the basis for important interventions in the established energy system (e.g. reform of the electricity market [74]). The UK is also an example of a country where energy models, in particular ESOMs, have come to form an important part of an active science-policy interface (see [75] and [76]).

In order to explore actor behaviour, transition pathways in the energy system that deviate from strict economic rationality are modelled in the context of other key uncertainties such as fuel prices and technology costs. Energy transitions in different sectors resulting from the use of a social planning perspective and cost-optimal behaviour are compared against counterfactual cases where actors make a range of heterogeneous choices, some of them non-optimal, and have different perspectives on valuing the future.

The remainder of the paper is structured as follows:

- Section 2.0 briefly outlines some of the key features of BLUE, the energy model used in the study

- Section 3.o describes the analytical approach taken in the paper for exploring behavioural uncertainties in energy transitions

- Section 4.0 presents the results of the model-based analysis, covering how transitions in key sectors (power, residential, road transport) are affected by different behavioural assumptions

- Section 5.0 discusses the main findings of the paper, including the implications for policymaking and future research

- Section 6.o draws together the key insights from the paper and presents the author's conclusions about the value of modelling non-optimal behaviour in decarbonisation pathway analysis 
The Behaviour, Lifestyles and Uncertainty Energy model (BLUE), is a system dynamic model of the UK energy system that simulates technological change, energy use, and emissions. BLUE features multiple energy technologies in a bounded system framework, several heterogeneous actors whose decisions can influence the direction of energy transitions, and includes time horizons suitable for long term policy assessment. Detailed information on the model structure, operation and inputs (including, for example, the mathematical equations and data sources used) can be found in the Appendix for this paper. Readers may also wish to refer to the online model documentation [77], which is periodically updated to reflect the latest changes to the model.

The conceptual topology of BLUE is shown below in Figure 1. Briefly, the landscape module (1) contains key system-wide parameters such as demand drivers, fuel costs, and user-defined policy interventions such as pollution taxes on GHG emissions. The regime supply module (2) is a single actor responsible for balancing energy demand and supply in the electricity and primary fuel systems. The regime demand module (3) comprises multiple actors, each being an independent social planner whose decisions affect their own economic sector. The niche developments (4) that can be explored in BLUE include exogenous changes to technology costs through time as well as changes to lifestyles, which affect end-use energy demand.

Figure 1 - Behaviour Lifestyles and Uncertainty Energy (BLUE) Model

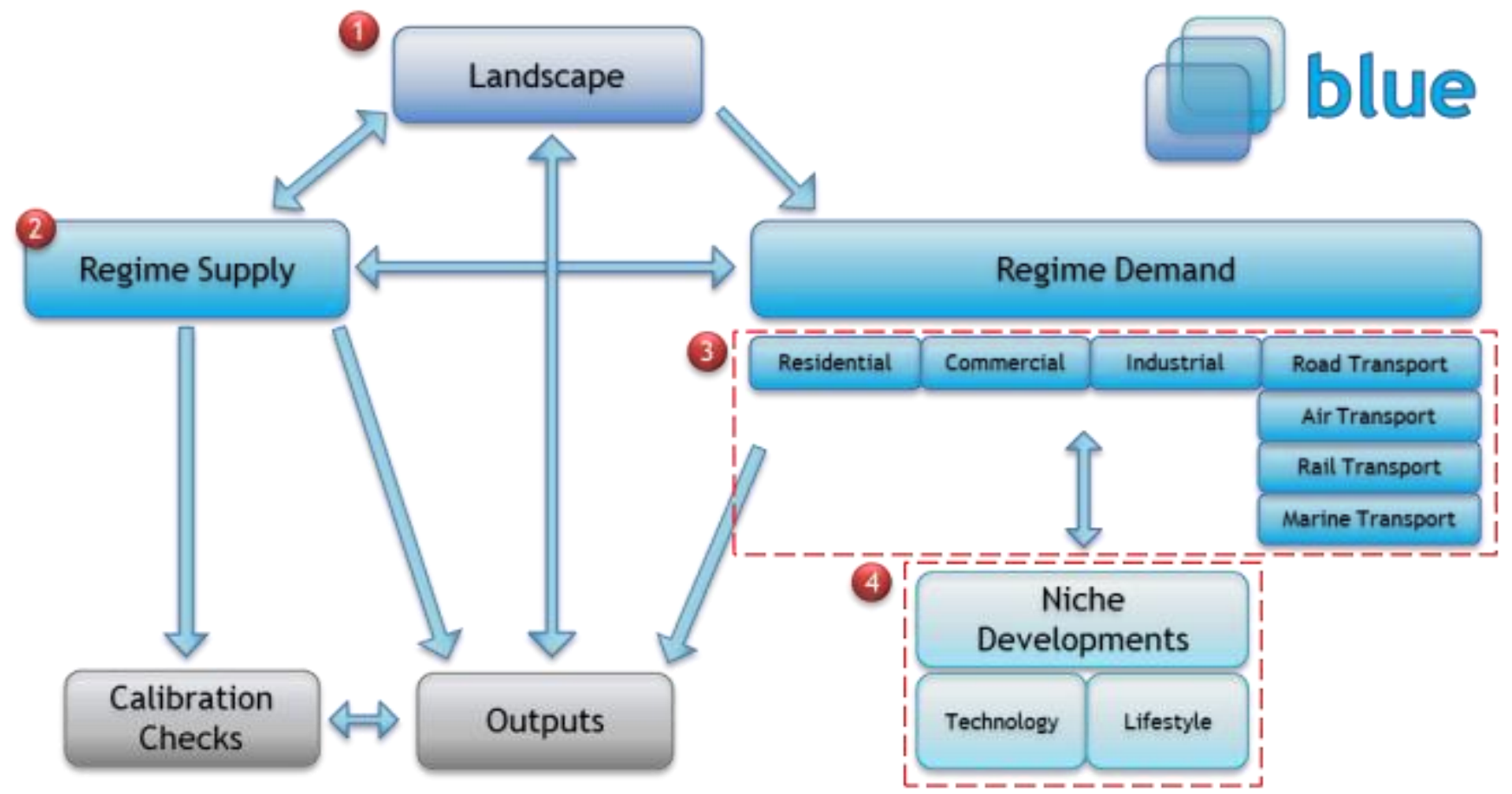

Energy demand growth in BLUE occurs over time in response to the exogenous demand drivers in the landscape module. Nearly all other model inputs are captured 
as probabilistic distributions to reflect uncertainty in both technology costs and actor behavioural parameters, with stochastic Monte Carlo simulation (typically with $n=500$ or greater) used to understand the potential variation in pathways across the time horizon. As the capital stock in each sector (heating systems, transport fleets etc.) ages and needs replacing, the individual energy system actors each make myopic decisions about investments based on their own differentiated micro-economic perspectives on how to value new technologies. The supply actor not only has to cyclically replace aging generation plant, but also has to respond to any growth in demand from other sectors over time. The myopic formulation can be characterised as being of the "limited foresight" type (actor decisions are made in a series of discrete time horizons that do not overlap) in the taxonomy of Keppo and Strubegger [36], rather than the "moving decision window" approach. As a result of the myopic model formulation, none of the actors have advance knowledge of the future decisions of any of the other stakeholders in the system, producing a dynamic series of interactions through time, partially addressing the requirement to improve representation of actors and institutions in the energy system ([62] and [63], see Section 1.2.1). Exogenous changes to policies, technology costs and lifestyles that occur across the time horizon have the potential to affect the direction of the energy transition.

In order to answer the call in the literature for better representation of microeconomic decision making ([6o] and [61], see Section 1.2.2), individual sector actors in BLUE can be configured with different behavioural parameters. Demand elasticities for each actor reflects their sensitivity to changes in energy prices i.e. whether and by how much they might curtail their energy use in response to price increases. Intangible costs or benefits for different actors can be used to ty and capture nonmonetary costs/benefits of different technology choices. Hurdle rates can be used to indicate the extent to which different actors value the present compared to the future and their resulting attitudes towards investments with high up front capital costs. Market heterogeneity in each sector represents the degree to which various actors exhibit "cost optimising behaviour" i.e. how relative cost differentials between competing investment options are viewed in the decision making process.

The model is designed to be computationally light weight and able to solve quickly for large numbers of Monte Carlo runs. Supply-demand balances are resolved through recursive simulation, with power system requirements determined using a simple peak demand equation that distinguishes between the ability of different technologies to contribute to base load generation capacity. The model focuses on the energy system, and interactions with the wider macro economy are not captured endogenously. Future updates to BLUE, which is under active development, may expand the model functionality in these areas but do not feature in the version used for this paper.

\subsection{Analytical Approach}

To investigate the effect of including a broader variety of behavioural assumptions in energy systems modelling, a number of stylised decarbonisation trajectories are modelled for the UK. As well as illustrating idealised conditions that approximate the type of cost-optimal decisions and friction-free policy environments often found in 
cost optimisation models, non-optimal behaviour is also explored. Three different sets of conditions for policy implementation $\left(\mathbf{P}_{\mathbf{1}}, \mathbf{P}_{\mathbf{2}}, \mathbf{P}_{\mathbf{3}}\right)$ and three different sets of behavioural assumptions ( $\left.\mathbf{B}_{\mathbf{1}}, \mathbf{B} \mathbf{2}, \mathbf{B} 3\right)$ are investigated for a total of nine scenarios.

In order to capture parametric uncertainties in many of the underlying parameters such as cost and technology performance, most inputs are captured as probabilistic distributions (for a full list of assumptions and parameters, readers should refer to the Appendix).

\subsection{Technology and resource assumptions}

All scenarios are run with the same settings for technology and resources. Future improvements in low carbon technologies are represented by having their costs reduce over time at uncertain rates, representing exogenous technological change. Uncertainty in future fuel costs for all scenarios are captured as triangular distributions that reflect the UK Government's perspective on high, low, and central cases for coal, oil, and natural gas prices [78], while the various components of generation plant costs (capital expenditure, operational expenditure, etc.) are also implemented as distributions based on data from government commissioned studies [77]. Ranges for capturing uncertainty in the current and future costs and performance of building heating technologies and road vehicles are taken from various industry and government sources, generally as uniform distributions [77].

The following analysis assumes that carbon capture and storage (CCS) infrastructure will become commercially available in the UK from 2030 onwards at the earliest, as UK efforts to begin technology demonstration programmes this decade have suffered significant delays [79]. Decarbonisation pathway modelling is often extremely sensitive to the availability of bioenergy, because when combined with CCS, this allows models to follow a negative emissions sequestration strategy [80]. The wisdom of relying on an approach that hopes to remove greenhouse gases from the atmosphere in future decades rather than preventing its release in the first instance is the subject of significant controversy in the climate policy community (e.g. [81] and [82]). Bioenergy availability in the analysis presented is aligned with the upper end of the range found in the work of the UK Committee on Climate Change (the statutory climate regulator), which is around 500 TWh, or $1800 \mathrm{PJ}$ ([83] and [84]). These constraints allow for some bioenergy CCS (BECCS) deployment, but they prevent a negative emissions approach from dominating the energy transition pathways explored.

\subsection{Policy conditions}

The ability of government to pass legislation that drives transitions towards new low carbon technologies is represented by a range of deterministic, exogenous carbon price trajectories, described in Table 1 . Despite climate targets for the UK being written into law, the long term sustainability of the UK Climate Change Act 2008 and the level of commitment that future governments will ascribe to climate policy remains uncertain and therefore represents a significant risk to future low carbon transitions [85]. 
In lieu of detailed modelling of policy instruments, such as an actual carbon tax, the carbon price is used here to represent the level of effective government action on emissions mitigation. As well as modelling an idealised future where strong mitigation action is applied consistently over the time horizon, cases where political barriers or changing levels of ambition result in sub-optimal policymaking (represented by volatile or weak carbon price signals) are also considered. Carbon pricing is based on the UK Government's projected trajectories for the traded value of $\mathrm{CO}_{2}$ between 2010 and 2050 [74].

Table 1-Policy conditions

\begin{tabular}{|c|c|c|c|}
\hline Reference & Name & Description & BLUE Parameters \\
\hline$P_{1}$ & Idealised policy & $\begin{array}{l}\text { This illustrates a stylised future } \\
\text { where the UK Government is able to } \\
\text { drive a transition towards a low } \\
\text { carbon future with few barriers to } \\
\text { implementation. }\end{array}$ & $\begin{array}{l}\text { This case applies the UK } \\
\text { Government's high trajectory for } \mathrm{CO}_{2} \\
\text { pricing without any volatility. This } \\
\text { reaches } 300 \mathrm{f} / \mathrm{tCO} \text { by } 2050[74] \text {. }\end{array}$ \\
\hline $\mathrm{P}_{2}$ & $\begin{array}{l}\text { Second-best } \\
\text { Policy }\end{array}$ & $\begin{array}{l}\text { This case implies that the } \\
\text { Government implements policies } \\
\text { aimed at transitioning the energy } \\
\text { system towards low carbon } \\
\text { technologies, but allows for some } \\
\text { volatility. This captures a future } \\
\text { transition where government } \\
\text { policies are not always consistent, } \\
\text { where government must contend } \\
\text { with powerful vested interests, and } \\
\text { where not all market externalities } \\
\text { can be internalised. }\end{array}$ & $\begin{array}{l}\text { This case applies an uncertain } \\
\text { distribution with the UK } \\
\text { Government's low }\left( \pm 100 / \mathrm{tCO}_{2}\right. \\
\text { by } 2050) \text { and high ( } ₫ 300 / \mathrm{tCO}_{2} \\
\text { by } 2050) \text { projections }[74] \text { i.e. } \\
\text { the effective carbon price in } \\
\text { any given year is randomly } \\
\text { sampled across the range. }\end{array}$ \\
\hline$P_{3}$ & $\begin{array}{c}\text { Dysfunctional } \\
\text { Policy }\end{array}$ & $\begin{array}{l}\text { This case implies a future where the } \\
\text { Government faces strong challenges } \\
\text { to passing effective legislation to } \\
\text { drive emissions mitigation and the } \\
\text { effective carbon price signal is both } \\
\text { lower and more volatile than in case } \\
\text { P2. Energy transitions may still occur } \\
\text { as relative costs for alternatives to } \\
\text { fossil fuel technologies change } \\
\text { through the modelled time horizon. }\end{array}$ & $\begin{array}{l}\text { This case applies an uncertain } \\
\text { distribution that is both wider and } \\
\text { lower than that found in } \mathrm{P}_{2} \text {. The UK } \\
\text { Government's low ( } f 100 / t \mathrm{CO}_{2} \text { by } \\
2050 \text { ) trajectory for } \mathrm{CO}_{2} \text { pricing is } \\
\text { taken as the upper boundary for the } \\
\text { distribution, while the lower bound is a } \\
\text { zero effective carbon price. }\end{array}$ \\
\hline
\end{tabular}

\subsection{Behavioural parameters}

Non-optimal actor behaviour is explored principally through varying the market heterogeneity and hurdle rate parameters in the BLUE model, both of which affect actor decision making with regard to technology investment:

i. Market heterogeneity affects the extent to which costs alone drive actor decision making. The brief literature review outlined earlier in Section 1.2.2 gives a rapid overview of the many factors besides costs that can 
affect individual choice. By default, actors can be configured with one of four illustrative ranges for market heterogeneity: cost optimising behaviour, strong price sensitivity, partial price sensitivity, or price insensitive behaviour. With cost optimising behaviour $(\boldsymbol{v}=20-50)$ actors will choose the least cost option almost every time, even if the economic benefits of doing so are very small. For example, at $\boldsymbol{v}=50$, a $5 \%$ saving between two competing technologies results in a $95 \%$ uptake of the cheaper option. For cases with more than two technologies, the relative differences in net present value dictate the market shares of the less "optimal" choices, as shown in the key equations documented in the Appendix. Under conditions of strong price sensitivity $(v=10-19)$ actors react strongly to prices, but prices do not entirely guide their decisions. For example, with $v=15$, a $>30 \%$ saving between options would be needed before an actor replaced their entire capital stock with the lowest cost alternative. When set to partial price sensitivity $(\boldsymbol{v}=5-9)$, actors are still price conscious but often require very large cost savings before undertaking a total switch to cheaper technologies. For example, at $\boldsymbol{v}=5, a>70 \%$ saving is required before an actor would choose to completely replace an incumbent technology with a lower cost alternative. Finally, if actors are configured with price insensitive behaviour $(\boldsymbol{v}=0-4)$, then they may not react strongly to prices at all, even if there are large potential cost savings to be made. With $\boldsymbol{v}=0$, actors will select equal shares of the available options. For example, if there are two competing technologies, then they will simply choose $50 \%$ of each, if there are three options, then the market will comprise a $33 \%$ share of each, and with four options, actors will purchase $25 \%$ of each.

ii. Hurdle rate settings affect actor sensitivity to up-front investment. As a result of their often strong influence on model outcomes, there is spirited debate over the appropriate use of hurdle rates in energy economic modelling which is beyond the scope of this paper, but which enters ethical and philosophical territory, such as questions of morality, intergenerational equity, and the role of the state [86]. The UK Government uses a social discount rate of 3.5\% for policy evaluation [87] and rates between 3-6\% are typical in European policy assessment [88]. However, there are a wide range of factors that cause individual choices to deviate from the social optimum. Individual actors are exposed to investment risks in the way which society at large is not because their assets are typically not as diversified [89]. Policy assessment is sometimes carried out using discount rates that approximate the typical financial cost of capital available to private companies and individuals e.g. 9-17\% [90] . Private discount rates revealed for individual decision making can be much higher and have even been estimated as being great as 30\%, 50\%, or even $80 \%$ [91].

Intangible costs are ignored for this study (i.e. set to zero), while demand elasticities take the default values from the documentation [77], which can also be found in the Appendix. 
Table 2 - Behavioural parameters

\begin{tabular}{|c|c|c|c|}
\hline Reference & Name & Description & BLUE Parameters \\
\hline B1 & $\begin{array}{l}\text { Cost-optimal } \\
\text { decisions, social } \\
\text { discounting }\end{array}$ & $\begin{array}{l}\text { These settings approximate the } \\
\text { representation of individual choice } \\
\text { found in a typical cost-optimisation } \\
\text { model } \\
\text { All actors are configured with cost } \\
\text { optimising behaviour } \\
\text { All actors take a long term social } \\
\text { planning perspective on valuing the } \\
\text { future }\end{array}$ & $\begin{array}{l}\text { The market heterogeneity parameter in } \\
\text { BLUE }(\boldsymbol{v}) \text { is set for all actors to be } \\
\text { between } \boldsymbol{v}=20 \text { and } \boldsymbol{v}=50 \\
\text { Hurdle rates ( } \boldsymbol{r} \text { ) of between } \boldsymbol{r}=3 \% \text { and } \\
r=6 \% \text { are used in evaluating } \\
\text { technology investments }\end{array}$ \\
\hline B2 & $\begin{array}{l}\text { Heterogeneous } \\
\text { decisions, social } \\
\text { discounting }\end{array}$ & $\begin{array}{l}\text { These settings are used to explore } \\
\text { futures where actor decision making } \\
\text { is not purely price-driven } \\
\text { The behaviour of firms is modelled } \\
\text { as being more cost driven than } \\
\text { individuals. The power, industry and } \\
\text { commercial sector actors are } \\
\text { modelled as having strong price } \\
\text { sensitivity. The residential and road } \\
\text { transport actors are modelled as } \\
\text { having partial price sensitivity } \\
\text { All actors are modelled as taking a } \\
\text { social perspective on investment } \\
\text { decisions }\end{array}$ & $\begin{array}{l}\text { The market heterogeneity } \\
\text { parameter in BLUE }(\boldsymbol{v}) \text { is set for } \\
\text { firms as being between } \boldsymbol{v}=10 \\
\text { and } \boldsymbol{v}=19 \text {, while for individuals } \\
\text { it is modelled as being between } \\
\boldsymbol{v}=5 \text { and } \boldsymbol{v}=10 \\
\text { Hurdle rates }(\boldsymbol{r}) \text { of between } \\
\boldsymbol{r}=3 \% \text { and } \boldsymbol{r}=6 \% \text { are used for all } \\
\text { actors }\end{array}$ \\
\hline B3 & $\begin{array}{l}\text { Heterogeneous } \\
\text { decisions, } \\
\text { individual } \\
\text { discounting }\end{array}$ & $\begin{array}{l}\text { As B2 but all actors are modelled as } \\
\text { taking an individual perspective on } \\
\text { investment decisions }\end{array}$ & $\begin{array}{l}\text { Hurdle rates }(r) \text { of between } \\
r=9 \% \text { and } r=17 \% \text { are used for all } \\
\text { actors }\end{array}$ \\
\hline
\end{tabular}

\subsection{Demand drivers}

For all scenarios, demand drivers in BLUE are deterministically aligned with the baseline projections for energy service demands used by the UK Government's Department for Business, Energy and Industrial Strategy (BEIS) in their UK TIMES model (UKTM) [92]. This model has been used by the Government as part of their approach to establishing a strategy for meeting the UK's Fifth Carbon Budget [93] and will inform the Governments' forthcoming Emissions Reduction Plan. Demand growth in the following analysis therefore reflects the Government's central 
perspective applied in their long term policy assessment activities, and includes for example, improvements to the thermal efficiency of the building stock, large increases in per capita demand for transport, particularly air travel, and a significant decline in the energy intensity of domestic industry.

\subsection{Results}

Multiple studies (e.g. [94], [95] and [96]) show that a UK climate mitigation strategy based around the rapid decarbonisation of the power grid followed by electrification of heating and road vehicles is likely to play a strong role in hitting national GHG reduction targets for 2050 . The results below first detail the outcomes found in the power, residential and road transport sectors, before moving on to illustrate the overall levels of emissions reductions achieved under the different behavioural scenarios assessed.

\subsection{Power sector}

Figure 2 illustrates technological change in the power sector, using the median results from the Monte Carlo simulations carried out for each scenario. The results are presented as a grid that compares the three sets of policy conditions discussed in Section $3.2\left(\mathbf{P}_{\mathbf{1}}, \mathbf{P}_{\mathbf{2}}, \mathbf{P}_{\mathbf{3}}\right)$ against the three sets of behavioural parameters outlined in Section 3.3 (B1, $\left.\mathbf{B}_{2}, \mathbf{B}_{\mathbf{3}}\right)$. The top left panel $\left(\mathbf{P}_{\mathbf{1}} \mathbf{B} \mathbf{1}\right)$, represents an energy transition that occurs under the conditions commonly assumed in cost optimisation models i.e. actors are rational agents who made choices based on costs, actors take a long term perspective on valuing the future when making investment decisions, and the government faces few barriers to effective implementation of energy policy measures. All of the other panels represent the modelled outcomes of transitions where actors do not behave according to these ideals. The bottom right panel for example $\left(\mathrm{P}_{3} \mathrm{~B}_{3}\right)$, represents an energy transition under challenging conditions. Here, actors are motivated by costs to varying degrees, but other factors influence their choices, actors are more risk averse and less forward thinking with their investment decisions, and government energy policy on climate mitigation is both weaker and more volatile than hoped for.

All nine scenarios represent differing degrees of technological change in the power sector. Policy conditions are a strong driver of change. It can be seen that under all scenarios the share of coal used for energy production (in grey) falls over time in response to the carbon price signals applied in the model. Both the $\mathbf{P}_{\mathbf{1}}$ (Idealised policy) and $\mathbf{P}_{\mathbf{2}}$ (Second-best policy) scenario sets achieve very strong transitions away from fossil fuels (coal, in grey, and unabated natural gas, in orange) towards low and zero carbon alternatives. Nuclear (red), wind (light and dark blue), solar photovoltaics (yellow) bioenergy with carbon capture and storage (deep green), and gas with carbon capture and storage (pale green) all feature in the transition. Carbon capture and storage technologies using coal are never deployed, as modelled costs never fall to levels where they actors deem them to be attractive. The $\mathrm{P}_{\mathbf{3}}$ (Dysfunctional policy) scenario set also sees a reduction in fossil fuel use, although as might be expected, this is more muted than in the other scenarios which have much stronger carbon 
pricing. In contrast to the $\mathbf{P}_{\mathbf{1}}$ and $\mathbf{P}_{\mathbf{2}}$ scenario sets, the role of nuclear of nuclear power is significantly reduced, and BECCS is not deployed in the $P_{3}$ scenarios.

Behavioural changes between scenarios introduce less pronounced, but nevertheless noticeable effects. Introducing heterogeneous choice i.e. moving from the B1 set (Cost-optimal decisions) to the B2 set (Heterogeneous decisions), does not produce a large difference in outcomes. This is because under the heterogeneous choice set of scenarios, the power sector is still represented as being strongly cost sensitive (if not perfectly cost optimal), as highlighted in Section 3.2 (Table 1), so broadly similar choices are made regarding technologies. Changing actor sensitivity to up-front costs, however, by moving from the B2 set (social discounting) to B3 set (individual discounting), has a much more visible impact. Low carbon alternatives to fossil fuels diffuse into the power system both later in the time horizon and at slower rates. More challenging policy conditions accentuate this effect. For example, in the case of scenario $\mathbf{P}_{\mathbf{3}} \mathbf{B}_{3}$, it can be seen that natural gas (orange) is still the dominant source of electricity generation by 2050 . 
Figure 2 - Power sector technology transitions (simulated median)

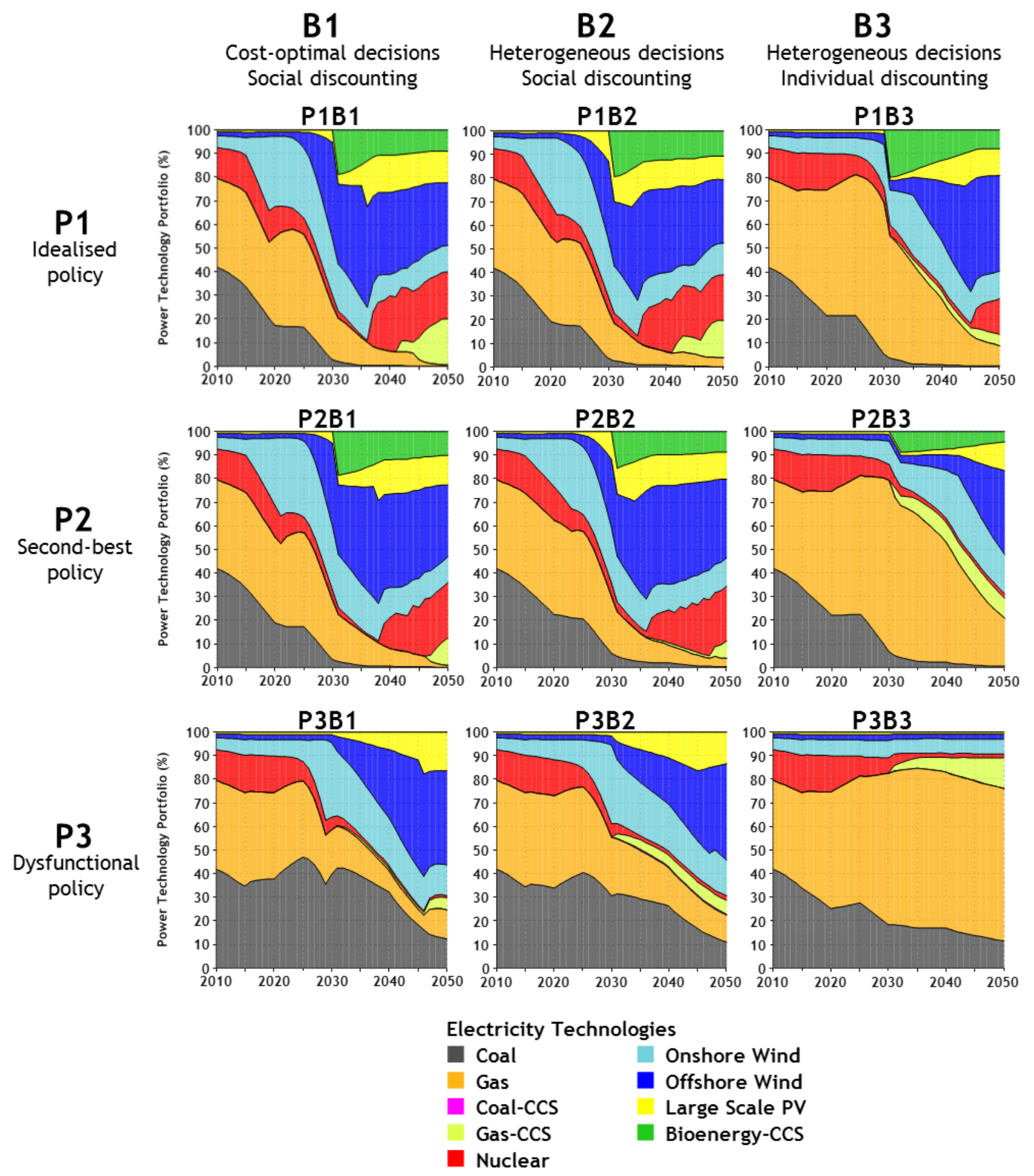

\subsection{Residential buildings}

Figure 3 summarises the changes to heating technologies observed in residential buildings, with median simulation results shown for each scenario. As with the previous panel chart shown for the power sector (Figure 2), each graph represents the outcome of a different set of policy and behavioural conditions. Panel P1B1 illustrates the outcome of a transition with model settings that approximate conditions found in a typical cost optimisation model. Under this idealised transition, 
the electrification of heat demand is strongly visible. As the electricity grid decarbonises and the costs of carbon-intensive heating using natural gas increases, gas boilers (in orange), lose relative market share to electrical heating solutions, including air source heat pumps (pink) and direct electric heating (pale yellow). Under $\mathrm{P}_{1} \mathrm{~B}_{1}$, more than half of the residential heating portfolio in 2050 is made up of air source heat pumps, supplied by low carbon electricity. However, as we introduce behavioural imperfections into our analysis, the results from the other 8 panels in Figure 3 show that this strong transition towards electrification is an outcome that is not universally replicated.

The weaker and more volatile carbon price signals introduced in the $\mathbf{P}_{\mathbf{2}}$ and $\mathbf{P} \mathbf{3}$ policy sets results in a slower adoption of electric heating or even a net reduction in electric heating. Although the costs of air source heat pumps do fall in the model between 2010 and 2050, the average cost of electricity is also increasing at the same time as a result of the deployment of large amounts of low carbon generation, as shown earlier in Section 4.1. Meanwhile, the model assumes that demand for building heating is falling as homes become, on average, more efficient over time. The increased costs of gas heating associated with the introduction of carbon pricing are therefore somewhat counterbalanced by the increased thermal efficiency of buildings. The net result is that, at the carbon prices modelled, low carbon electric heating either does not become cost competitive with gas boilers until relatively late in the time horizon $\left(\mathbf{P}_{\mathbf{2}}\right)$ or never becomes cost competitive $\left(\mathbf{P}_{\mathbf{3}}\right)$.

Introducing deviations from rational economic behaviour also works against the diffusion of electric heating in the residential sector. In particular, the use of an individual discounting perspective as opposed to a social discounting perspective is shown to radically curtail the uptake of air source heat pumps (for example, compare $\mathrm{P}_{1} \mathrm{~B}_{2}$ with $\mathrm{P}_{1} \mathrm{~B}_{3}$ ). This is likely to be as a result of the high up front capital cost differential assumed between heat pumps and individual gas boilers. 
Figure 3-Residential building technology transitions (simulated median)

B1

Cost-optimal decisions Social discounting
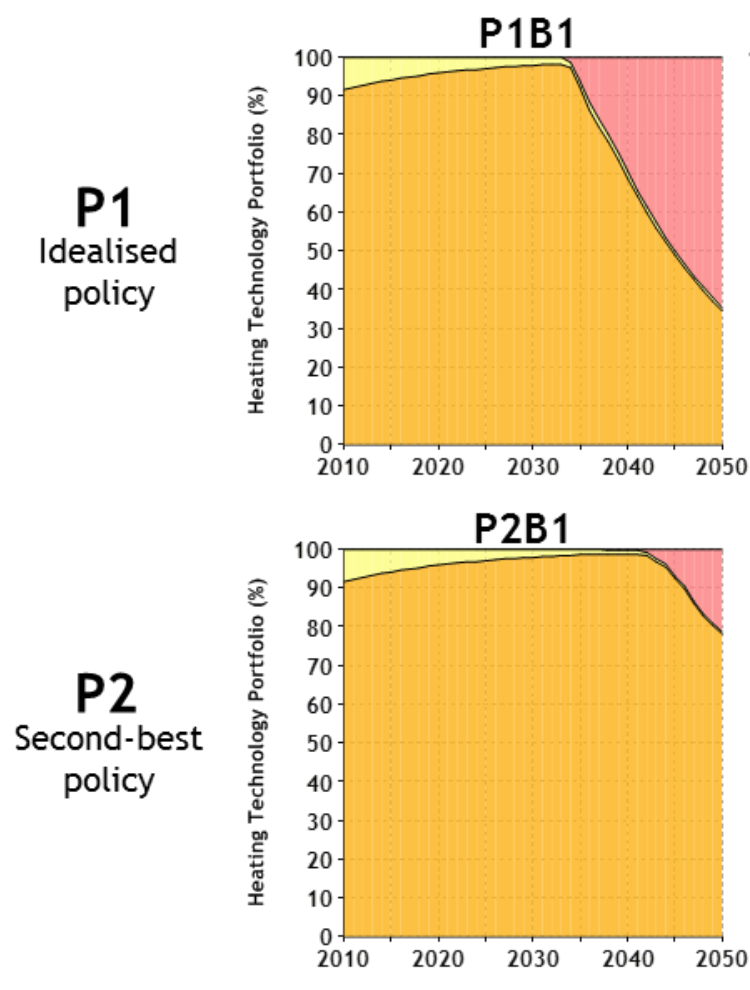

P2

Second-best

policy

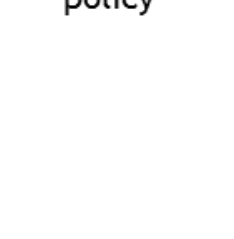

P3

Dysfunctional policy
B2

Heterogeneous decisions Social discounting
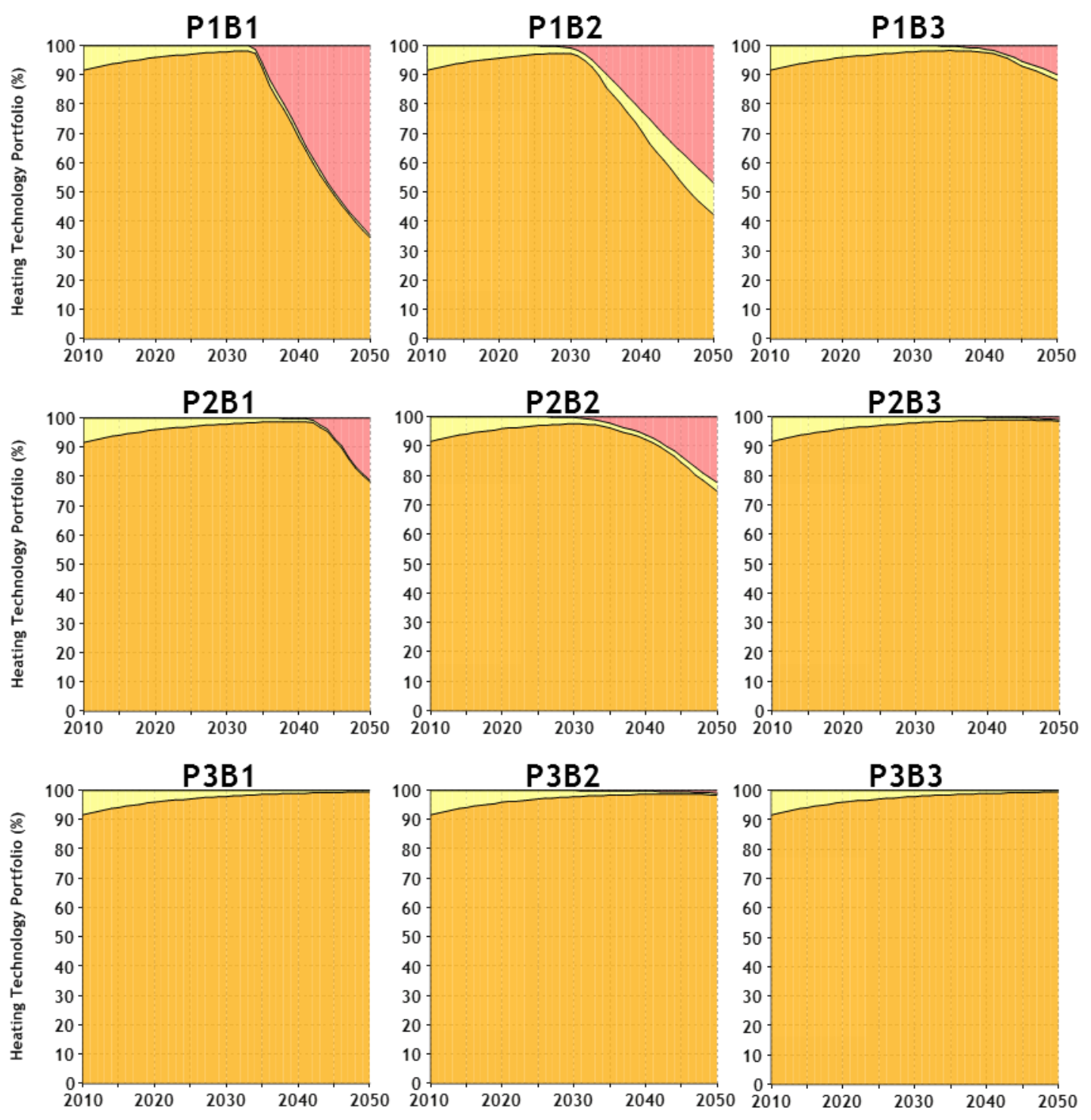

Residential Heat Technologies

Gas Boilers

Electric Resistive Heating

Air Source Heat Pumps 
Figure 4 shows the median simulated results for technological change in the road vehicle fleet under each of the nine scenarios assessed. The panels are laid out for comparison in the same fashion illustrated earlier for power generation (Section 4.1) and residential heating (Section 4.2). The idealised case ( $\left.\mathbf{P}_{1} \mathbf{B}_{1}\right)$ demonstrates a very strong trend towards the adoption of electric drivetrain vehicles in road transport, with the penetration of this technology in excess of $80 \%$ by 2050 . The high carbon price applied under Idealised policy conditions has the effect of eventually making electric vehicles cost competitive when compared to fossil fuel vehicles, after which, their market penetration rapidly increases. Under Second-best policy conditions ( $\left.\mathbf{P}_{2} \mathbf{B}_{1}, \mathbf{P}_{2} \mathbf{B}_{2}, \mathbf{P}_{2} \mathbf{B}_{3}\right)$, the more volatile carbon price leads to a less pronounced transition because the cost differential between electric vehicles and fossil fuel vehicles takes longer to close. The result is a $20-70 \%$ penetration of electric vehicles by 2050 , depending on the differentiated behavioural parameters applied.

Under Dysfunctional policy conditions $\left(\mathbf{P}_{3} \mathbf{B}_{1}, \mathbf{P}_{3} \mathbf{B}_{2}, \mathbf{P}_{3} \mathbf{B}_{3}\right)$ the behavioural assumptions display some counterintuitive effects that merit some additional explanation. Under the low and inconsistent carbon price found under Dysfunctional policy conditions, electric vehicles are consistently more expensive than their fossil fuel alternatives across the entire time horizon. Under $\left(\mathbf{P}_{3} \mathbf{B}_{1}\right)$, which has an assumption of cost optimal behaviour applied, there is therefore no net uptake of electric vehicles, because they are always the more expensive option, and because the decision is nearly entirely cost driven. This can be contrasted against the heterogeneous choice scenarios ( $\mathrm{P}_{3} \mathrm{~B}_{2}$ and $\left.\mathrm{P}_{3} \mathrm{~B}_{3}\right)$. Here, electric vehicles are still more expensive than fossil fuel vehicles, and the rational economic choice would still be to select the cheaper option. However, in these scenarios, consumers are assumed to be only partially price sensitive (see Table 2). As their choices are more heterogeneous, a fraction of the market is not deterred by the increased costs of electric vehicles and purchases them in spite of their higher costs. As discussed earlier in Section 1.2.2, non-price factors can often form strong determinants of decision making. Under scenarios $\mathbf{P}_{\mathbf{3}} \mathbf{B}_{\mathbf{2}}$ and $\mathbf{P}_{\mathbf{3}} \mathbf{B}_{\mathbf{3}}$, the model achieves a degree of market penetration of electric vehicles of between $7-20 \%$ depending on the discount rate assumptions used. 
Figure 4-Road transport technology transitions (simulated median)

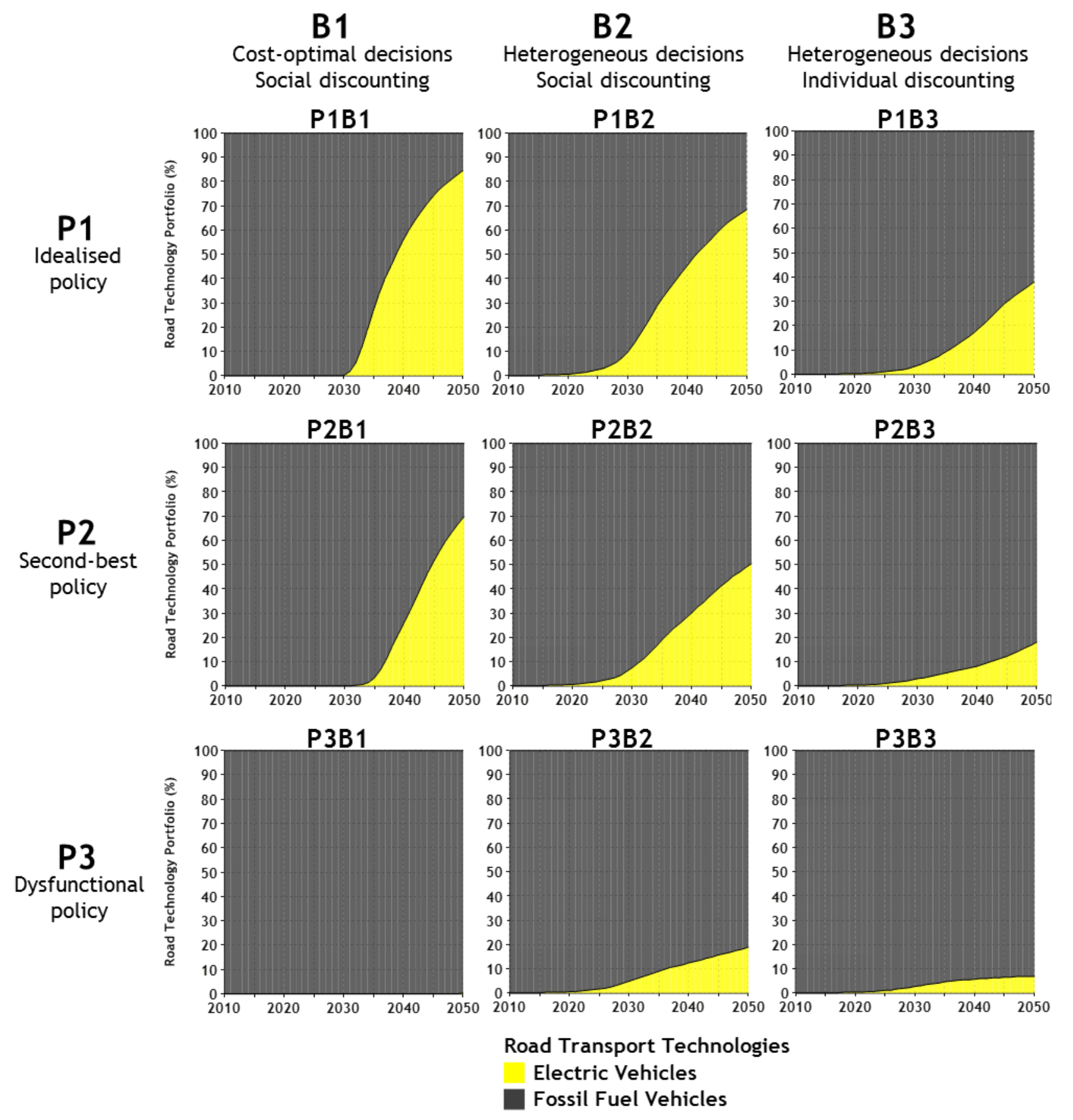


Figure 5 illustrates the distribution of modelled $\mathrm{GHG}$ emissions levels in $\mathrm{MtCO}_{2}$ for each of the nine scenarios assessed, using the full range of outputs from the Monte Carlo analysis. Each vertically spaced chart represents one of the three different sets of modelled policy conditions ( $\mathbf{P}_{\mathbf{1}}, \mathbf{P}_{\mathbf{2}}, \mathbf{P}_{\mathbf{3}}$ ), while the different coloured lines on each chart represent the probability density of outputs for each set of behavioural

parameters ( $\left.\mathbf{B}_{\mathbf{1}}, \mathbf{B}_{\mathbf{2}}, \mathbf{B}_{\mathbf{3}}\right)$. The light red shaded area indicates approximately the range $146-180 \mathrm{MtCO}_{2}$, which the UK Committee on Climate Change (CCC) has assessed as the maximum carbon budget for the UK in 2050 that is likely to be consistent with conditions of global equity on a per capita basis i.e. where the UK population will not emit more GHGs per person than any other country [97]. This target makes implicit assumptions about global population and the sensitivity of the climate response to GHG emissions, and may be revised in future, perhaps to include a "net-zero" emissions target (e.g. as discussed in [98]). But put simply, to hit the UK's emissions targets for 2050 that are currently written into law [73], the energy system should be at or ideally below these levels by 2050 .

It can be seen immediately that regardless of the behavioural assumptions used ( $\mathbf{B}_{\mathbf{1}}$, $\left.\mathbf{B}_{2}, \mathbf{B}_{3}\right)$, none of the simulated model runs under the $\mathbf{P}_{\mathbf{3}}$ set of conditions (Dysfunctional policy) came close to achieving UK climate targets, even when accounting for the wide range of outcomes for fuel costs and technology performance between 2010 - 2050. Under the P2 set of conditions (Second-best policy) there are visible differences in outcomes related to the behaviour settings. The assumption of cost-optimal behaviour and social discount rates ( $\mathbf{B} \mathbf{1}$ and $\mathbf{B} \mathbf{2}$ ) causes the model to meet or exceed UK climate targets under some, but not all scenarios. If heterogeneous behaviour and individual discounting are assumed on the other hand (B3), then none of the simulated model runs come close to achieving the UK's GHG targets. Finally, under the $\mathbf{P}_{\mathbf{1}}$ set of conditions (Idealised policy), the results show that most, but not all scenarios with cost-optimal behaviour and/or social discount rates (B1 and B2) achieve climate targets, whereas most, but again, not all, scenarios with heterogeneous behaviour and individual discounting (B3) fail to meet climate targets.

Overall, the analysis demonstrates that where energy system actors are assumed to make less than perfectly cost-optimal investment choices or are assumed to take an individual discounting perspective on valuing the future, then progress on climate mitigation at any given level of government effort has the potential to be significantly impeded. 
Figure 5- Probability density of UK emissions in 2050

- B1 Cost-optimal decisions, Social discounting

- B2 Heterogeneous decisions, Social discounting

- B3 Heterogeneous decisions, Individual discounting
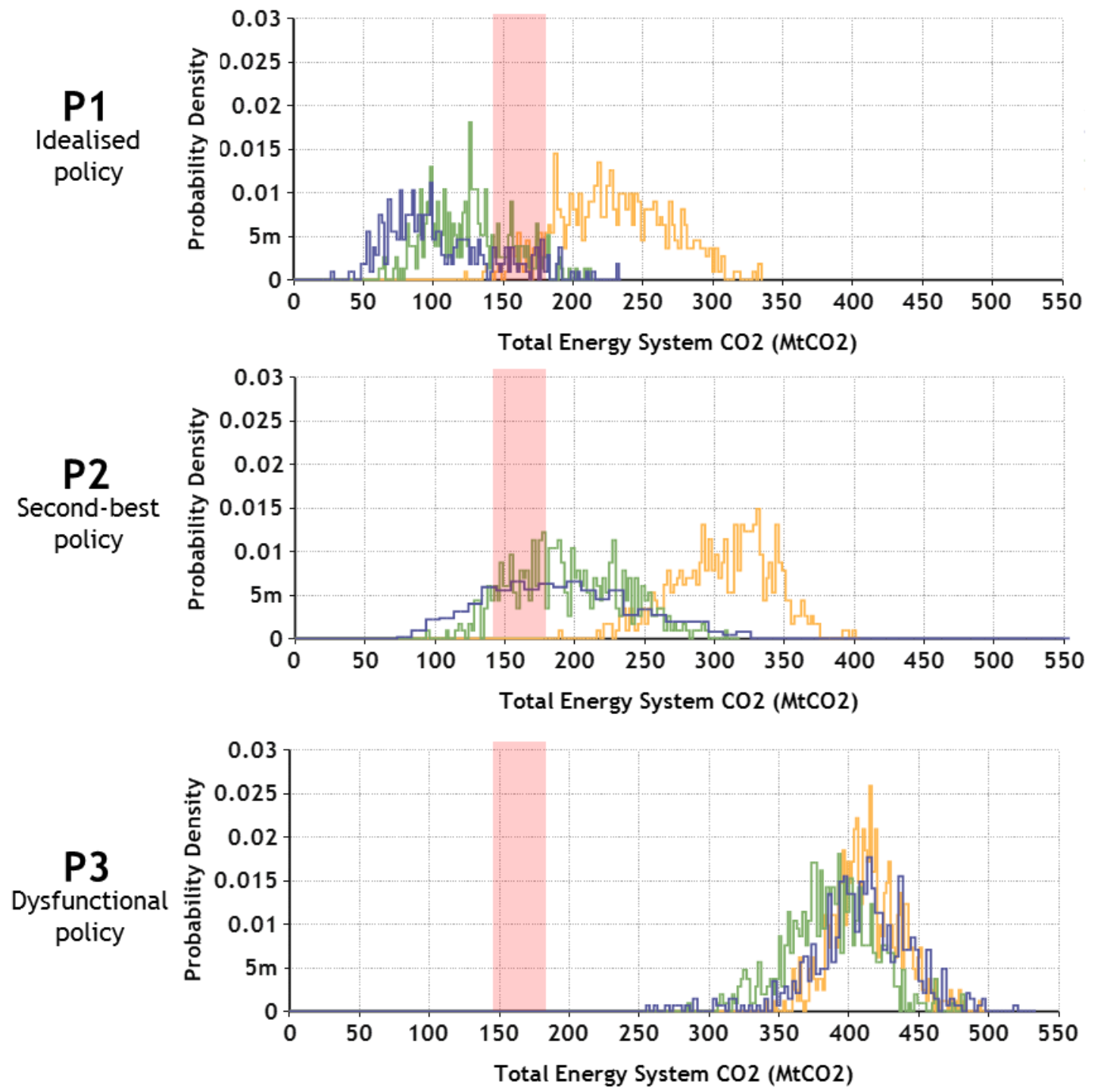


\subsection{Key insights from results}

The results in Section 4.0 illustrate the difficulty of achieving deep decarbonisation targets when actors interact in a myopic fashion with no advance knowledge of future conditions, even under the influence of strong carbon price signals. They show that behavioural considerations can be at least as important as technological factors. In particular, deviation from purely rational choice behaviour is likely to hinder, rather than help, climate mitigation efforts, as price signals for internalising the costs of GHG pollution have a dampened effect when actors are less price conscious. Finally, the results illustrate that anything less than idealised policymaking, where strong and consistent signals are sent to penalise carbon polluting technologies, risks failure. The results have been contrasted here against model runs that show idealised conditions and perfectly rational actors i.e. the conditions that approximate the outputs from many typical energy systems optimisation models (ESOMs).

The analysis demonstrates the potential fragility of strategies based on the assumption that price signals sent by policymakers will be tightly geared to actual actor responses in the energy system. The diffusion of technologies in end-use sectors that are dominated by consumer choices, for example, may not play out as hoped for, due to the potentially strong effect of non-monetary factors in individual decision making by private citizens. This suggests that either government must engage strongly with consumers in an attempt to influence future choice behaviour or that policymakers should take a precautionary approach in areas such as home heating and personal mobility as part of their overall decarbonisation strategy. This may mean for example, that for achieving interim targets, government might need to pursue strategies to reduce GHGs more aggressively in areas where it exerts more direct influence (e.g. power, industry), in order to hedge against the risk of consumerdriven sectors underperforming. A third possible interpretation is that price instruments are not the first-best policy design option for a number of key sectors, and government might need to consider applying normative standards that regulate away the opportunity for consumers to make environmentally damaging choices.

\subsection{Neglect of behavioural dimensions in mainstream analysis}

In writing this piece, the author risks being accused of belabouring the obvious: that ambitious climate policy may be extremely difficult to deliver, and that dysfunctional politics combined with erratic behaviour could well lead to decarbonisation targets being missed. A pre-emptive rejoinder then, is needed, lest this paper be seen as redundant: If it is obvious that individual choice behaviour and political dynamics are major drivers of energy transitions, then why is it routine practice for them to be abstracted away, ignored, or sidestepped in quantitative energy policy analysis? If analysts know that politics is a volatile business, and that individual choices are complex, why does much model-based research persist in representing these elements with smooth trends and simple relationships? 
The author advances two hypotheses for discussion. The first is that the apparent aversion to considering socio-political factors stems from either a lack of opportunities for interdisciplinary training or an unwillingness to engage in interdisciplinary research within institutions that often lead energy policy analysis. There has been a historic preoccupation within contemporary energy research with engineering and economic factors, and a tendency for diverse fields of social science such as "history, sociology, philosophy, political science, and psychology" to be afforded only second-tier status [99]. This is not an issue that is unique to whole economy decarbonisation pathway analysis, but one observed in many areas across the field. For example, it has been common practice for years for prominent building energy demand models to assume temperature profiles for heating that are completely divorced from occupant behaviour ([100] and [101]), with the result that conclusions drawn for policymaking from the model outputs can be entirely misleading [102].

The second hypothesis is that the framing of key policy and research challenges and the expectations from government and research funding agencies tend to be for outputs that are deterministic in character. Decision makers often display a reluctance towards contemplating various degrees of incertitude or indeterminacy of information, and as a result energy modellers are often pressured to provide simple explanations and recommendations ([103] and [104]). In this environment, something as complex and intractable as "actor behaviour" can fall easily into the bucket of things that are uncertain and difficult to model, and which then becomes easily relegated to a footnote in the assumptions section of a report rather than a prominent driver of the analysis undertaken. This challenge can be accentuated in policy environments where naïve overconfidence in the effectiveness of market mechanisms is pervasive [105], because efforts to question or explore uncertainties around the essential rationality of economic actors are met with at best, indifference and at worst, ridicule. Finally, there is often a wider reluctance by policymakers to discuss or contemplate analysis that shows policy failure, because in the political arena failure is frequently punished rather than being seen as a learning opportunity.

\subsection{Implications for research and science-policy discourse}

Regardless of the veracity of the two hypotheses discussed above, the risks of the status quo continuing are significant. National level policymakers risk focusing on a few deterministic model runs with narrowly defined assumptions and ignoring the need to undertake a broader analysis of uncertainties, including behaviour. This gives the appearance of certainty where none exists, closing down debate and ultimately leading to ineffective policy design ([103] and [75]). Researchers engaged in advising policymakers should caution strongly against this trend and encourage analysis that embraces key uncertainties and encompasses a diversity of outcomes, including the potential for policy failure. In this context, ESOMs are powerful tools for normative assessment of decarbonisation pathways but there is an increasing need for more exploratory analysis aimed at investigating the dynamics of future energy transitions and assessing climate target feasibility in so-called "second best" worlds where political factors render certain market failures impossible to correct [49]. 
There is a greater need for interdisciplinary research that integrates the social and behavioural drivers of energy systems alongside the technological and the economic ([106] and [107]). The analysis presented in this paper illustrates that even with identical technology and resource assumptions, the behavioural and political dimensions to deep decarbonisation pathways can effectively make or break the viability of an energy transition. This is arguably neither emphasised sufficiently nor explored with much enthusiasm in many policy assessments for future energy systems, which tend to overlook behavioural complexity [62].

Technologies do not evolve in isolation from society or the economy (see [108], [109], and [110]). There is no doubt that behavioural parameters are complex to estimate from empirical data and to translate into quantitative models [111]. But that does not mean that uncertainties linked to actor behaviour can be safely assumed to have a negligible effect. There is a strong case for further research investigating both the micro-economic decisions of individual actors and how different key decision makers in the energy system interact and respond to one another. Energy modelling must also embrace the uncertain nature of energy transitions and the real possibility of failure in climate policy in order to assist in developing realistic strategies for achieving desirable outcomes. Nothing is gained from spinning future fictions of easy success.

The energy modelling community is already making steps towards exploring secondbest insights by introducing resource or technology deployment constraints to mimic real-world barriers (e.g. [112]) or introducing delays to represent inertia in decision making (e.g. [113]). Model users can mimic non-cost barriers to technology diffusion by using hurdle rates and heterogeneous decision making [114], incorporating behavioural demand responses to higher energy prices using price elasticities of demand [115], or implementing myopic foresight (e.g. [116], [117]). This paper has illustrated one such approach in a system dynamic model that combines all of the above elements, but further research is clearly needed for these techniques to become widespread.

More explicit modelling of actors and institutions may require new approaches, such as exploratory modelling with new tools that try to integrate techno-economic detail, actor heterogeneity and transition pathway dynamics [118], or attempts to "bridge" [119] between analytical disciplines such as quantitative modelling and sociotechnical transitions studies (e.g. [120] and [121]). It is also possible that for meaningful policy engagement, models might need to be applied in a more iterative, participatory fashion with key decision makers [76], following a "modelling as a service" strategy where policymakers participate more actively in the process, rather than a "modelling as a product" approach where analysis is undertaken remotely from stakeholders and later presented as a fait accompli [122].

\subsection{Conclusions}

This paper started by discussing the real political and social barriers to climate mitigation efforts that arise from the interactions of multiple actors and the microeconomic behaviours that influence their investment decisions. A failure to account for these effects is arguably already leading to poor policy design for energy transitions. It is common practice in much of the literature to abstract the interactions 
of multiple stakeholders into a single, all-powerful decision maker that handles resource allocation on the basis of maximising social utility. It is also typical to assume that price setting policies will translate directly into economically rational, "optimal" choices across a wide range of diverse actors.

Both of these assumptions are abstractions from complex real world phenomena that must not be overlooked, as they represent key drivers of energy system change. An improved depiction of human factors is urgently required in order to improve the utility of energy economic models for policy assessment. Not doing so risks producing well-meaning analysis that implies that ambitious decarbonisation targets remain comfortably within reach, when in fact this is only true in so-called "first best" policy futures where all externalities can be internalised, and where all decision makers behave as rational utility-maximising agents.

This paper has attempted to challenge the common assumptions about how actors in the energy system might behave using a stochastic system dynamic model of the UK energy system, the Behaviour Lifestyles and Uncertainty Energy model (BLUE). The work illustrates energy transitions featuring multiple actors, acting with myopic foresight, heterogeneous choice behaviour, and with varying perspectives on valuing the future. The results show that the dynamics of multiple actors, making nonoptimal micro-economic investment decisions, has the potential to derail strategies for deep decarbonisation that assume cost optimal choice behaviour and render ambitious GHG reduction targets extremely difficult to achieve. This raises important questions as to why the deep uncertainties associated with human behaviour are routinely overlooked in policy assessment. The implications are that model-based energy systems research should in future aim to take a more explicitly socio-technical perspective, or at the very least, to clearly include significant behavioural and political uncertainties in the analysis framework, not just as footnotes.

Returning then, to the title of this piece: what is the value of modelling "actors behaving badly"? The work presented in this paper serves as an illustration of the potential fragility of analysis based on cost-optimisation approaches, unless backed by a rigorous assessment of behavioural and political uncertainties. If something as simple as the assumption that people might not behave exactly as hoped for or that politics might interfere with clear market signals is enough to blow apart a carefully constructed strategy for transitioning society to a low carbon future, then surely, these strategies must be re-examined and subjected to greater scrutiny? Researchers cannot know what the future holds for technologies, the economy, or society. But history shows that politics can be messy and that people are often risk averse and mercurial.

Energy systems modelling plays an important role in international efforts to avoid environmental decline, population displacement, increased early mortality, and the other undesirable outcomes associated with a rapidly warming world. The energy modelling community is forward thinking, ambitious, and committed to working with policymakers to find solutions to some of the grand challenges of our time. The work presented in this paper demonstrates the value in questioning the basis for some of the key assumptions found in our models, and how we use them to inform decisions made under conditions of deep uncertainty. These questions are uncomfortable because they challenge deeply held conventions and belief structures on both sides of the science-policy interface. We should ask them more often. 
This paper builds on research carried out under the "Whole Systems Energy Modelling Consortium (wholeSEM)" project funded by the UK Engineering and Physical Sciences Research Council (EPSRC) under Grant EP/K039326/1. The views expressed here are those of the author alone. An earlier version of this work was presented at the $35^{\text {th }}$ International Energy Workshop (IEW 2016) which took place on $1^{\text {st }}-3^{\text {rd }}$ June 2016 in Cork, Republic of Ireland.

\subsection{References}

[1] UNFCCC, Adoption of the Paris Agreement: Proposal by the President: Draft decision -/CP.21, United Nations Framework Convention on Climate Change (UNFCCC), 2015. http://unfccc.int/resource/docs/2015/cop21/eng/logro1.pdf.

[2] A.A. Fawcett, G.C. lyer, L.E. Clarke, J.A. Edmonds, N.E. Hultman, H.C. McJeon, J. Rogelj, R. Schuler, J. Alsalam, G.R. Asrar, J. Creason, M. Jeong, J. McFarland, A. Mundra, W. Shi, Can Paris pledges avert severe climate change?, Science (80-. ). 350 (2015) 1168-1169. doi:10.1126/science.aad5761.

[3] J. Rogelj, M. den Elzen, N. Höhne, T. Fransen, H. Fekete, H. Winkler, R. Schaeffer, F. Sha, K. Riahi, M. Meinshausen, Paris Agreement climate proposals need a boost to keep warming well below $2{ }^{\circ} \mathrm{C}$, Nature. 534 (2016) 631-639. doi:10.1038/nature18307.

[4] M.R. Raupach, S.J. Davis, G.P. Peters, R.M. Andrew, J.G. Canadell, P. Ciais, P. Friedlingstein, F. Jotzo, D.P. van Vuuren, C. Le Quéré, Sharing a quota on cumulative carbon emissions, Nat. Clim. Chang. 4 (2014) 873-879. doi:10.1038/nclimate2384.

[5] M.E. Mann, Defining dangerous anthropogenic interference, Proc. Natl. Acad. Sci. 106 (2009) 4065-4066. doi:10.1073/pnas.0901303106.

[6] S. Randalls, History of the $2^{\circ} \mathrm{C}$ climate target, Wiley Interdiscip. Rev. Clim. Chang. 1 (2010) 598-605. doi:10.1002/wcc.62.

[7] K. Anderson, A. Bows, Beyond "dangerous" climate change: emission scenarios for a new world, Philos. Trans. R. Soc. A Math. Phys. Eng. Sci. 369 (2011) 20-44. doi:10.1098/rsta.2010.0290.

[8] Deep Decarbonization Pathways Project, Pathways to deep decarbonization 2015 report, SDSN - IDDRI, 2015. http://deepdecarbonization.org/wpcontent/uploads/2015/12/DDPP_2015_REPORT.pdf.

[9] S. Pye, C. Bataille, Improving deep decarbonization modelling capacity for developed and developing country contexts, Clim. Policy. 16 (2016) S27-S46. doi:10.1080/14693062.2016.1173004.

[10] N. Strachan, S. Pye, R. Kannan, The iterative contribution and relevance of modelling to UK energy policy, Energy Policy. 37 (2009) 850-860. doi:10.1016/j.enpol.2008.09.096.

[11] L. Clarke, K. Jiang, K. Akimoto, M. Babiker, G. Blanford, K. Fisher-Vanden, J.-C. Hourcade, V. Krey, E. Kriegler, A. Löschel, D. McCollum, S. Paltsev, S. Rose, P.R. Shukla, M. Tavoni, B.C.C. van der Zwaan, D.P. van Vuuren, Assessing Transformation Pathways, in: O. Edenhofer, R. Pichs-Madruga, Y. Sokona, E. Farahani, S. Kadner, K. Seyboth, A. Adler, I. Baum, S. Brunner, P. Eickemeier, 
B. Kriemann, J. Savolainen, S. Schlömer, V. Stechow, T. Zwickel, J.C. Minx (Eds.), Clim. Chang. 2014 Mitig. Clim. Chang. Contrib. Work. Gr. III to Fifth Assess. Rep. Intergov. Panel Clim. Chang., Cambridge University Press, Cambridge, United Kingdom and New York, NY, USA, 2014: pp. 413-510. https://www.ipcc.ch/pdf/assessmentreport/ar5/wg3/ipcc_wg3_ar5_chapter6.pdf.

[12] S. Pye, C. McGlade, C. Bataille, G. Anandarajah, A. Denis-Ryan, V. Potashnikov, Exploring national decarbonization pathways and global energy trade flows: a multi-scale analysis, Clim. Policy. 16 (2016) S92-S109.

doi:10.1080/14693062.2016.1179619.

[13] F.G.N. Li, E. Trutnevyte, N. Strachan, A review of socio-technical energy transition (STET) models, Technol. Forecast. Soc. Change. 100 (2015) 290-305. doi:10.1016/j.techfore.2015.07.017.

[14] S. Jebaraj, S. Iniyan, A review of energy models, Renew. Sustain. Energy Rev. 10 (2006) 281-311. doi:10.1016/j.rser.2004.09.004.

[15] S.C. Bhattacharyya, G.R. Timilsina, A review of energy system models, Int. J. Energy Sect. Manag. 4 (2010) 494-518. doi:10.1108/17506221011092742.

[16] S. Pfenninger, A. Hawkes, J. Keirstead, Energy systems modeling for twentyfirst century energy challenges, Renew. Sustain. Energy Rev. 33 (2014) 74-86. doi:10.1016/j.rser.2014.02.003.

[17] L. Börjeson, M. Höjer, K.-H. Dreborg, T. Ekvall, G. Finnveden, Scenario types and techniques: Towards a user's guide, Futures. 38 (2006) 723-739. doi:10.1016/j.futures.2005.12.002.

[18] R.J. Lempert, A new decision sciences for complex systems, Proc. Natl. Acad. Sci. 99 (2002) 7309-7313. doi:10.1073/pnas.082081699.

[19] J.H. Williams, A. DeBenedictis, R. Ghanadan, A. Mahone, J. Moore, W.R. Morrow, S. Price, M.S. Torn, The Technology Path to Deep Greenhouse Gas Emissions Cuts by 2050: The Pivotal Role of Electricity, Science (80-. ). 335 (2012) 53-59. doi:10.1126/science.1208365.

[20] N. Strachan, R. Kannan, Hybrid modelling of long-term carbon reduction scenarios for the UK, Energy Econ. 30 (2008) 2947-2963. doi:10.1016/j.eneco.2008.04.009.

[21] F. Amorim, A. Pina, H. Gerbelová, P. Pereira da Silva, J. Vasconcelos, V. Martins, Electricity decarbonisation pathways for 2050 in Portugal: A TIMES (The Integrated MARKAL-EFOM System) based approach in closed versus open systems modelling, Energy. 69 (2014) 104-112. doi:10.1016/j.energy.2014.01.052.

[22] J.-C. Hourcade, M. Jaccard, C. Bataille, F. Ghersi, Hybrid Modeling: New Answers to Old Challenges Introduction to the Special Issue of The Energy Journal, Energy J. Sl2006 (2006). doi:10.5547/ISSNo195-6574-EJ-VolSI2006NoSl2-1.

[23] M. Howells, H. Rogner, N. Strachan, C. Heaps, H. Huntington, S. Kypreos, A. Hughes, S. Silveira, J. DeCarolis, M. Bazillian, A. Roehrl, OSeMOSYS: The Open Source Energy Modeling System, Energy Policy. 39 (2011) 5850-5870. doi:10.1016/j.enpol.2011.06.033.

[24] L.G. Fishbone, H. Abilock, Markal, a linear-programming model for energy systems analysis: Technical description of the BNL version, Int. J. Energy Res. 5 (1981) 353-375. doi:10.1002/er.4440050406.

[25] R. Loulou, M. Labriet, ETSAP-TIAM: the TIMES integrated assessment model Part I: Model structure, Comput. Manag. Sci. 5 (2008) 7-40. doi:10.1007/s10287- 
007-0046-z.

[26] J.F. DeCarolis, S. Babaee, B. Li, S. Kanungo, Modelling to generate alternatives with an energy system optimization model, Environ. Model. Softw. 79 (2016) 300-310. doi:10.1016/j.envsoft.2015.11.019.

[27] F.G.N. Li, E. Trutnevyte, Investment appraisal of cost-optimal and near-optimal pathways for the UK electricity sector transition to 2050, Appl. Energy. 189 (2017) 89-109. doi:10.1016/j.apenergy.2016.12.047.

[28] E. Trutnevyte, Does cost optimization approximate the real-world energy transition?, Energy. (2016). doi:0.1016/j.energy.2016.03.038.

[29] B. Keepin, B. Wynne, Technical analysis of IIASA energy scenarios, Nature. 312 (1984) 691-695. doi:10.1038/312691ao.

[30] C. Bertram, N. Johnson, G. Luderer, K. Riahi, M. Isaac, J. Eom, Carbon lock-in through capital stock inertia associated with weak near-term climate policies, Technol. Forecast. Soc. Change. 90 (2015) 62-72. doi:10.1016/j.techfore.2013.10.001.

[31] W. McDowall, E. Trutnevyte, J. Tomei, I. Keppo, Reflecting on Scenarios, UK Energy Research Centre (UKERC), London, UK, 2014. http://www.ukerc.ac.uk/publications/ukerc-energy-systems-theme-reflectingon-scenarios.html.

[32] E. Trutnevyte, C. Guivarch, R. Lempert, N. Strachan, Reinvigorating the scenario technique to expand uncertainty consideration, Clim. Change. 135 (2016) 373-379. doi:10.1007/s10584-015-1585-x.

[33] S. Pye, W. Usher, N. Strachan, The uncertain but critical role of demand reduction in meeting long-term energy decarbonisation targets, Energy Policy. 73 (2014) 575-586. doi:10.1016/j.enpol.2014.05.025.

[34] J.F. DeCarolis, Using modeling to generate alternatives (MGA) to expand our thinking on energy futures, Energy Econ. 33 (2011) 145-152. doi:10.1016/j.eneco.2010.05.002.

[35] G.J. Blanford, E. Kriegler, M. Tavoni, Harmonization vs. fragmentation: overview of climate policy scenarios in EMF27, Clim. Change. 123 (2014) 383396. doi:10.1007/s10584-013-0951-9.

[36] I. Keppo, M. Strubegger, Short term decisions for long term problems - The effect of foresight on model based energy systems analysis, Energy. 35 (2010) 2033-2042. doi:10.1016/j.energy.2010.01.019.

[37] M. Labriet, C. Nicolas, S. Tchung-Ming, A. Kanudia, R. Loulou, Energy Decisions in an Uncertain Climate and Technology Outlook: How Stochastic and Robust Methodologies Can Assist Policy-Makers, in: G. Giannakidis, M. Labriet, B. Ó Gallachóir, G. Tosato (Eds.), Informing Energy Clim. Policies Using Energy Syst. Model., Springer International Publishing, 2015: pp. 69-91. doi:10.1007/978-3-319-16540-0_4.

[38] M. Dowson, A. Poole, D. Harrison, G. Susman, Domestic UK retrofit challenge: Barriers, incentives and current performance leading into the Green Deal, Energy Policy. 50 (2012) 294-305. doi:10.1016/j.enpol.2012.07.019.

[39] R. Galvin, Why German homeowners are reluctant to retrofit, Build. Res. Inf. 42 (2014) 398-408. doi:10.1080/09613218.2014.882738.

[40] A.B. Jaffe, R.N. Stavins, The energy-efficiency gap What does it mean?, Energy Policy. 22 (1994) 804-810. doi:10.1016/0301-4215(94)90138-4.

[41] A.B. Jaffe, R.N. Stavins, Energy-Efficiency Investments and Public Policy, Energy J. 15 (1994). doi:10.5547/ISSNo195-6574-EJ-Vol15-No2-3.

[42] R.D. Marchand, S.C.L. Koh, J.C. Morris, Delivering energy efficiency and carbon 
reduction schemes in England: Lessons from Green Deal Pioneer Places, Energy Policy. 84 (2015) 96-106. doi:10.1016/j.enpol.2015.04.035.

[43] NAO, Green Deal and Energy Company Obligation, National Audit Office (NAO), London, UK, 2016. https://www.nao.org.uk/report/green-deal-andenergy-company-obligation/.

[44] R. Fouquet, P.J.G. Pearson, Seven Centuries of Energy Services: The Price and Use of Light in the United Kingdom (1300-2000), Energy J. 27 (2006). doi:10.5547/ISSNo195-6574-EJ-Vol27-No1-8.

[45] B.K. Sovacool, Early modes of transport in the United States: Lessons for modern energy policymakers, Policy Soc. 27 (2009) 411-427. doi:10.1016/j.polsoc.2009.01.006.

[46] R. Fouquet, The slow search for solutions: Lessons from historical energy transitions by sector and service, Energy Policy. 38 (2010) 6586-6596. doi:10.1016/j.enpol.2010.06.029.

[47] C. Wilson, A. Grübler, Lessons from the history of technological change for clean energy scenarios and policies, Nat. Resour. Forum. 35 (2011) 165-184. doi:10.1111/j.1477-8947.2011.01386.x.

[48] A. Grubler, C. Wilson, G. Nemet, Apples, oranges, and consistent comparisons of the temporal dynamics of energy transitions, Energy Res. Soc. Sci. 22 (2016) 18-25. doi:10.1016/j.erss.2016.08.015.

[49] R.G. Lipsey, K. Lancaster, The General Theory of Second Best, Rev. Econ. Stud. 24 (1956) 11. doi:10.2307/2296233.

[50] L.S. Bennear, R.N. Stavins, Second-best theory and the use of multiple policy instruments, Environ. Resour. Econ. 37 (2007) 111-129. doi:10.1007/s10640-0079110-y.

[51] J. Eom, J. Edmonds, V. Krey, N. Johnson, T. Longden, G. Luderer, K. Riahi, D.P. Van Vuuren, The impact of near-term climate policy choices on technology and emission transition pathways, Technol. Forecast. Soc. Change. 90 (2015) 73-88. doi:10.1016/j.techfore.2013.09.017.

[52] P.A. Samuelson, W.D. Nordhaus, Economics, 12th ed., McGraw-Hill, 1985.

[53] J.S. Black, P.C. Stern, J.T. Elworth, Personal and contextual influences on househould energy adaptations., J. Appl. Psychol. 70 (1985) 3-21. doi:10.1037/0021-9010.70.1.3.

[54] J. Johnson Brown, P.H. Reingen, Social Ties and Word-of-Mouth Referral Behavior, J. Consum. Res. 14 (1987) 350. doi:10.1086/209118.

[55] P. Mau, J. Eyzaguirre, M. Jaccard, C. Collins-Dodd, K. Tiedemann, The "neighbor effect": Simulating dynamics in consumer preferences for new vehicle technologies, Ecol. Econ. 68 (2008) 504-516. doi:10.1016/j.ecolecon.2008.05.007.

[56] L. Neij, L. Mundaca, E. Moukhametshina, Choice-decision determinants for the (non) adoption of energy efficiency technologies in households, in: Eceee 2009 Summer Study (European Counc. an Energy Effic. Econ. Act! Innov. Deliv. Reducing Energy Demand Sustain., 2009: pp. 687-695. http://www.eceee.org/library/conference_proceedings/eceee_Summer_Studie s/2009/Panel_3/3.285.

[57] H.A. Simon, A Behavioral Model of Rational Choice, Q. J. Econ. 69 (1955) 99. doi:10.2307/1884852.

[58] H.A. Simon, Rational choice and the structure of the environment., Psychol. Rev. 63 (1956) 129-138. doi:10.1037/hoo42769.

[59] J. Axsen, K.S. Kurani, Social Influence, Consumer Behavior, and Low-Carbon 
Energy Transitions, Annu. Rev. Environ. Resour. 37 (2012) 311-340.

doi:10.1146/annurev-environ-062111-145049.

[6o] C. Wilson, H. Dowlatabadi, Models of Decision Making and Residential Energy Use, Annu. Rev. Environ. Resour. 32 (2007) 169-203.

doi:10.1146/annurev.energy.32.053006.141137.

[61] L. Mundaca, L. Neij, E. Worrell, M. McNeil, Evaluating Energy Efficiency Policies with Energy-Economy Models, Annu. Rev. Environ. Resour. 35 (2010) 305-344. doi:10.1146/annurev-environ-052810-164840.

[62] N. Hughes, N. Strachan, Methodological review of UK and international low carbon scenarios, Energy Policy. 38 (2010) 6056-6065. doi:10.1016/j.enpol.2010.05.061.

[63] E. Trutnevyte, W. McDowall, J. Tomei, I. Keppo, Energy scenario choices: Insights from a retrospective review of UK energy futures, Renew. Sustain. Energy Rev. 55 (2016) 326-337. doi:10.1016/j.rser.2015.10.067.

[64] P. Kyle, S.H. Kim, Long-term implications of alternative light-duty vehicle technologies for global greenhouse gas emissions and primary energy demands, Energy Policy. 39 (2011) 3012-3024. doi:10.1016/j.enpol.2011.03.016.

[65] V. Daioglou, B.J. van Ruijven, D.P. van Vuuren, Model projections for household energy use in developing countries, Energy. 37 (2012) 601-615. doi:10.1016/j.energy.2011.10.044.

[66] D.L. McCollum, C. Wilson, H. Pettifor, K. Ramea, V. Krey, K. Riahi, C. Bertram, Z. Lin, O.Y. Edelenbosch, S. Fujisawa, Improving the behavioral realism of global integrated assessment models: An application to consumers' vehicle choices, Transp. Res. Part D Transp. Environ. (2016). doi:10.1016/j.trd.2016.04.003.

[67] H.E. Daly, K. Ramea, A. Chiodi, S. Yeh, M. Gargiulo, B. Ó Gallachóir, Modal Shift of Passenger Transport in a TIMES Model: Application to Ireland and California, in: G. Giannakidis, G., Labriet, M., Ó Gallachóir, B., Tosato (Ed.), Informing Energy Clim. Policies Using Energy Syst. Model. Lect. Notes Energy 30, Springer International Publishing, 2015: pp. 279-291. doi:10.1007/978-3319-16540-0_16.

[68] N. Rivers, M. Jaccard, Combining Top-Down and Bottom-Up Approaches to Energy-Economy Modeling Using Discrete Choice Methods, Energy J. 26 (2005). doi:10.5547/ISSN0195-6574-EJ-Vol26-No1-4.

[69] L.-G. Giraudet, C. Guivarch, P. Quirion, Exploring the potential for energy conservation in French households through hybrid modeling, Energy Econ. 34 (2012) 426-445. doi:10.1016/j.eneco.2011.07.010.

[70] M.D. Gerst, P. Wang, A. Roventini, G. Fagiolo, G. Dosi, R.B. Howarth, M.E. Borsuk, Agent-based modeling of climate policy: An introduction to the ENGAGE multi-level model framework, Environ. Model. Softw. 44 (2013) 6275. doi:10.1016/j.envsoft.2012.09.002.

[71] M.D. Gerst, P. Wang, M.E. Borsuk, Discovering plausible energy and economic futures under global change using multidimensional scenario discovery, Environ. Model. Softw. 44 (2013) 76-86. doi:10.1016/j.envsoft.2012.09.001.

[72] J.-F. Mercure, H. Pollitt, A.M. Bassi, J.E. Viñuales, N.R. Edwards, Modelling complex systems of heterogeneous agents to better design sustainability transitions policy, Glob. Environ. Chang. 37 (2016) 102-115. doi:10.1016/j.gloenvcha.2016.02.003.

[73] HM Government, Climate Change Act 2008, HMSO, London, UK, 2008. http://www.legislation.gov.uk/ukpga/2008/27/pdfs/ukpga_20080027_en.pdf. 
[74] HM Government, Energy Bill, Her Majesty's Stationery Office (HMSO), London, UK, 2012. http://services.parliament.uk/bills/2012-13/energy.html.

[75] P.G. Taylor, P. Upham, W. McDowall, D. Christopherson, Energy model, boundary object and societal lens: 35 years of the MARKAL model in the UK, Energy Res. Soc. Sci. 4 (2014) 32-41. doi:10.1016/j.erss.2014.08.007.

[76] N. Strachan, B. Fais, H. Daly, Reinventing the energy modelling-policy interface, Nat. Energy. 1 (2016) 16012. doi:10.1038/nenergy.2016.12.

[77] F.G.N. Li, N. Strachan, BLUE: Behaviour Lifestyles and Uncertainty Energy model, Online Documentation Revision 02, Version 1.9.4_RI, November 2016, UCL Energy Institute, London, UK, 2016. https://www.ucl.ac.uk/energymodels/models/blue.

[78] DECC, DECC Fossil Fuel Price Projections, July 2013 (URN 13D/170), Department of Energy and Climate Change (DECC), London, UK, 2013. https://www.gov.uk/government/uploads/system/uploads/attachment_data/fil e/212521/130718_decc-fossil-fuel-price-projections.pdf.

[79] House Of Commons Energy and Climate Change Committee, Future of carbon capture and storage in the UK: Second report of session 2015-16, House of Commons, London, UK, 2016.

http://www.parliament.uk/business/committees/committees-a-z/commonsselect/energy-and-climate-change-committee/news-parliament-2015/ccsreport-published-15-16/.

[80] S. Fuss, J.G. Canadell, G.P. Peters, M. Tavoni, R.M. Andrew, P. Ciais, R.B. Jackson, C.D. Jones, F. Kraxner, N. Nakicenovic, C. Le Quéré, M.R. Raupach, A. Sharifi, P. Smith, Y. Yamagata, Betting on negative emissions, Nat. Clim. Chang. 4 (2014) 850-853. doi:10.1038/nclimate2392.

[81] P. Smith, S.J. Davis, F. Creutzig, S. Fuss, J. Minx, B. Gabrielle, E. Kato, R.B. Jackson, A. Cowie, E. Kriegler, D.P. van Vuuren, J. Rogelj, P. Ciais, J. Milne, J.G. Canadell, D. McCollum, G. Peters, R. Andrew, V. Krey, G. Shrestha, P. Friedlingstein, T. Gasser, A. Grübler, W.K. Heidug, M. Jonas, C.D. Jones, F. Kraxner, E. Littleton, J. Lowe, J.R. Moreira, N. Nakicenovic, M. Obersteiner, A. Patwardhan, M. Rogner, E. Rubin, A. Sharifi, A. Torvanger, Y. Yamagata, J. Edmonds, $C$. Yongsung, Biophysical and economic limits to negative $\mathrm{CO}_{2}$ emissions, Nat. Clim. Chang. 6 (2015) 42-50. doi:10.1038/nclimate2870.

[82] K. Anderson, G. Peters, The trouble with negative emissions, Science (80-. ). 354 (2016) 182-183. doi:10.1126/science.aah4567.

[83] CCC, Bioenergy Review, The Committee on Climate Change (CCC), London, UK, 2011. http://www.theccc.org.uk/reports/bioenergy-review.

[84] CCC, Bioenergy Review: Technical Paper 2: Global and UK Bioenergy Supply Scenarios, The Committee on Climate Change (CCC), London, UK, 2011. http://archive.theccc.org.uk/aws2/Bioenergy/1463.

[85] M. Lockwood, The political sustainability of climate policy: The case of the UK Climate Change Act, Glob. Environ. Chang. 23 (2013) 1339-1348. doi:10.1016/j.gloenvcha.2013.07.001.

[86] D. Moellendorf, Discounting the Future and the Morality in Climate Change Economics, in: Moral Chall. Danger. Clim. Chang., Cambridge University Press, New York, 2013: pp. 90-122. doi:10.1017/CBO9781139083652.005.

[87] HM Treasury, The Green Book: Appraisal and Evaluation in Central Government, London, UK, 2011. http://www.hmtreasury.gov.uk/d/green_book_complete.pdf.

[88] A.H. Hermelink, D. de Jager, Evaluating our Future: The Crucial Role of 
Discount Rates in European Commission Energy System Modelling, Ecofys for The European Council for an Energy Efficient Economy (eceee), 2015. http://europeanclimate.org/evaluating-our-future-the-crucial-role-of-discountrates-in-european-commission-energy-system-modelling/.

[89] R.J. Sutherland, Market Barriers to Energy-Efficiency Investments, Energy J. 12 (1991). doi:10.5547/ISSNo195-6574-EJ-Vol12-No3-3.

[90] H. Pollitt, S. Billington, The Use of Discount Rates in Policy Modelling, Cambridge Econometrics, 2015.

http://www.camecon.com/Libraries/Downloadable_Files/The_use_of_Discount _Rates_in_Policy_Modelling.sflb.ashx.

[91] J. Nyober, Simulating Evolution of Technology: An Aid to Energy Policy Analysis, Simon Fraser University, 1997.

http://www.collectionscanada.gc.ca/obj/s4/f2/dsk3/ftpo4/nq24339.pdf.

[92] B. Fais, N. Sabio, N. Strachan, The critical role of the industrial sector in reaching long-term emission reduction, energy efficiency and renewable targets, Appl. Energy. 162 (2016) 699-712. doi:10.1016/j.apenergy.2015.10.112.

[93] CCC, The Fifth Carbon Budget: The next step towards a low-carbon economy, The Committee on Climate Change (CCC), London, UK, 2015.

https://www.theccc.org.uk/publication/the-fifth-carbon-budget-the-next-steptowards-a-low-carbon-economy/.

[94] P. Ekins, G. Anandarajah, N. Strachan, Towards a low-carbon economy: scenarios and policies for the UK, Clim. Policy. 11 (2011) 865-882.

doi:10.3763/cpol.2010.0126.

[95] P. Ekins, N. Strachan, I. Keppo, W. Usher, J. Skea, G. Anandarajah, UKERC Research Report: The UK Energy System in 2050: Comparing Low-Carbon, Resilient Scenarios, UK Energy Research Centre (UKERC), London, UK, 2013. http://www.ukerc.ac.uk/publications/the-uk-energy-system-in-2050comparing-low-carbon-resilient-scenarios.html.

[96] S. Pye, G. Anandarajah, B. Fais, C. McGlade, N. Strachan, Pathways to Deep Decarbonization in the United Kingdom, IDDRI, SDSN and UCL Energy Institute, 2015. http://deepdecarbonization.org/wpcontent/uploads/2015/og/DDPP_GBR.pdf.

[97] CCC, Building a low-carbon economy - the UK's contribution to tackling climate change, The Committee on Climate Change (CCC), London, UK, 2008.

[98] S. Pye, F.G.N. Li, J. Price, B. Fais, Achieving net-zero emissions through the reframing of UK national targets in the post-Paris Agreement era, Nat. Energy. (2017).

[99] B.K. Sovacool, What are we doing here? Analyzing fifteen years of energy scholarship and proposing a social science research agenda, Energy Res. Soc. Sci. 1 (2014) 1-29. doi:10.1016/j.erss. 2014.02.003.

[100] S. Kelly, D. Crawford-Brown, M.G. Pollitt, Building performance evaluation and certification in the UK: Is SAP fit for purpose?, Renew. Sustain. Energy Rev. 16 (2012) 6861-6878. doi:10.1016/j.rser.2012.07.018.

[101] S. Kelly, M. Shipworth, D. Shipworth, M. Gentry, A. Wright, M. Pollitt, D. Crawford-Brown, K. Lomas, Predicting the diversity of internal temperatures from the English residential sector using panel methods, Appl. Energy. 102 (2013) 601-621. doi:10.1016/j.apenergy.2012.08.015.

[102] E. Cayre, B. Allibe, M.-H. Laurent, D. Osso, There are people in the house! How the results of purely technical analysis of residential energy consumption are misleading for energy policies, in: Eceee 2011 Summer Study (European Counc. 
an Energy Effic. Econ. Energy Effic. First Found. a Low-Carbon Soc., Belambra Presqu'île de Giens, France, 2011.

http://proceedings.eceee.org/papers/proceedings2011/7-

277_Cayre.pdf?returnurl=http://proceedings.eceee.org/visabstrakt.php?event= 1.

[103] A. Stirling, Keep it complex, Nature. 468 (2010) 1029-1031. doi:10.1038/4681029a.

[104] M.G. Morgan, Our Knowledge of the World is Often Not Simple: Policymakers Should Not Duck that Fact, But Should Deal with It, Risk Anal. 35 (2015) 19-20. doi:10.1111/risa.12306.

[105] P.S. Mallaburn, N. Eyre, Lessons from energy efficiency policy and programmesin the UK from 1973 to 2013, Energy Effic. 7 (2014) 23-41. doi:10.1007/s12053-013-9197-7.

[106] A. Yatchew, Economics of energy, big ideas for the non-economist, Energy Res. Soc. Sci. 1 (2014) 74-82. doi:10.1016/j.erss.2014.03.004.

[107] M. Grubb, J.-C. Hourcade, K. Neuhoff, The Three Domains structure of energyclimate transitions, Technol. Forecast. Soc. Change. 98 (2015) 290-302. doi:10.1016/j.techfore.2015.05.009.

[108] J. Rotmans, R. Kemp, M. van Asselt, More evolution than revolution: transition management in public policy, Foresight. 3 (2001) 15-31. doi:10.1108/14636680110803003.

[109] F. Berkhout, A. Smith, A. Stirling, Socio-technological regimes and transition contexts, in: B. Elzen, F.W. Geels, K. Green (Eds.), Syst. Innov. Transit. to Sustain. Theory, Evid. Policy, Edward Elgar, Cheltenham, UK, 2004: pp. 48-75. http://www.e-elgar.co.uk/bookentry_main.lasso?id=3335.

[110] F.W. Geels, Technological Transitions and System Innovations: A Coevolutionary and Socio-Technical Analysis, Edward Elgar, Cheltenham, UK, 2005. doi:10.4337/9781845424596.

[111] J.C. Driscoll, S. Holden, Behavioral economics and macroeconomic models, J. Macroecon. 41 (2014) 133-147. doi:10.1016/j.jmacro.2014.05.004.

[112] N. Strachan, W. Usher, Failure to achieve stringent carbon reduction targets in a second-best policy world, Clim. Change. 113 (2011) 121-139. doi:10.1007/s10584-011-0267-6.

[113] M. Schaeffer, L. Gohar, E. Kriegler, J. Lowe, K. Riahi, D. van Vuuren, Mid- and long-term climate projections for fragmented and delayed-action scenarios, Technol. Forecast. Soc. Change. 90 (2015) 257-268. doi:10.1016/j.techfore.2013.09.013.

[114] M. Horne, M. Jaccard, K. Tiedemann, Improving behavioral realism in hybrid energy-economy models using discrete choice studies of personal transportation decisions, Energy Econ. 27 (2005) 59-77. doi:10.1016/j.eneco.2004.11.003.

[115] S. Pye, N. Sabio, N. Strachan, An integrated systematic analysis of uncertainties in UK energy transition pathways, Energy Policy. 87 (2015) 673684. doi:10.1016/j.enpol.2014.12.031.

[116] D. Martinsen, V. Krey, P. Markewitz, S. Vögele, A Time Step Energy Process Model for Germany - Model Structure and Results, Energy Stud. Rev. 14 (2006). doi:10.15173/esr.v14i1.480.

[117] F. Hedenus, C. Azar, K. Lindgren, Induced Technological Change in a Limited Foresight Optimization Model, Energy Journal, Spec. Issue Endog. Technol. Chang. Econ. Atmos. Stabilisation. 27 (2006) 109-122. doi:10.5547/ISSN0195- 
6574-EJ-VolSI2006-NoSI1-4.

[118] F.G.N. Li, N. Strachan, Modelling energy transitions for climate targets under landscape and actor inertia, Environ. Innov. Soc. Transitions. (2016). doi:10.1016/j.eist.2016.08.002.

[119] F.W. Geels, F. Berkhout, D.P. van Vuuren, Bridging analytical approaches for low-carbon transitions, Nat. Clim. Chang. 6 (2016) 576-583. doi:10.1038/nclimate2980.

[120] W. McDowall, Exploring possible transition pathways for hydrogen energy: A hybrid approach using socio-technical scenarios and energy system modelling, Futures. 63 (2014) 1-14. doi:10.1016/j.futures.2014.07.004.

[121] F.G.N. Li, S. Pye, N. Strachan, Regional winners and losers in future UK energy system transitions, Energy Strateg. Rev. 13-14 (2016) 11-31. doi:10.1016/j.esr.2016.08.002.

[122] R.J. Lempert, S.W. Popper, S.C. Bankes, Shaping the Next One Hundred Years: New Methods for Quantitative, Long-Term Policy Analysis. RAND report MR1626., RAND Corporation, RAND Corporation, The RAND Pardee Center, Santa Monica, CA, USA, 2003.

https://www.rand.org/content/dam/rand/pubs/monograph_reports/2007/MR16 26.pdf. 


\subsection{Appendix}

\subsection{Actor Behavioural Parameters}

The behavioural parameter ranges used in this study are given below in Table 1 .

Sector level actors in the BLUE model can be configured with:

- Demand elasticities $\boldsymbol{e}_{\boldsymbol{1}}$ describing actor sensitivity to changes in prices

- Market heterogeneity $\boldsymbol{v}$, describing actor propensity to cost-optimise

- Intangible costs $i$, describing actor perception of non-monetary costs

- Hurdle rates $r$, describing actor sensitivity to up-front investment

- Retrofitting/replacement rate $\boldsymbol{b}$, describing actor investment cycles

Table 3-Actor behaviour parameters ( $\mathrm{L}=\mathrm{Low}, \mathrm{C}=\mathrm{Central}, \mathrm{H}=\mathrm{High}$ )

\begin{tabular}{|c|c|c|c|c|c|c|c|c|}
\hline $\begin{array}{l}\text { Behavioural } \\
\text { Parameter }\end{array}$ & Power & Residential & Commercial & Industrial & $\begin{array}{l}\text { Transport } \\
\text { (Road) }\end{array}$ & $\begin{array}{l}\text { Transport } \\
\text { (Air) }\end{array}$ & $\begin{array}{l}\text { Transport } \\
\text { (Rail) }\end{array}$ & $\begin{array}{l}\text { Transport } \\
\text { (Marine) }\end{array}$ \\
\hline $\begin{array}{c}\text { Demand } \\
\text { elasticities }(\boldsymbol{e}), \\
\text { based on }[1]\end{array}$ & - & $\begin{array}{c}L=-0.1 \\
C=-0.25 \\
H=-0.40\end{array}$ & $\begin{array}{c}L=-0.01 \\
C=-0.1 \\
H=-0.15\end{array}$ & $\begin{array}{l}L=-0.01 \\
C=-0.03 \\
H=-0.05\end{array}$ & $\begin{array}{l}L=-0.15 \\
C=-0.30 \\
H=-0.50\end{array}$ & $\begin{array}{l}L=-0.40 \\
C=-0.70 \\
H=-1.00\end{array}$ & $\begin{array}{l}L=-0.60 \\
C=-0.80 \\
H=-1.10\end{array}$ & $\begin{array}{l}L=-0.01 \\
C=-0.03 \\
H=-0.06\end{array}$ \\
\hline $\begin{array}{c}\text { Market } \\
\text { heterogeneity } \\
(\boldsymbol{v}) \text {, see } \\
\text { Section } 4.3\end{array}$ & & & $\begin{array}{r}P \\
\text { Str } \\
\text { Cost }\end{array}$ & $\begin{array}{l}\text { Price insens } \\
\text { tial price ser } \\
\text { ng price sen }\end{array}$ & $\begin{array}{l}\mathrm{L}=0, \mathrm{H}=4 \\
\text { vity, } \mathrm{L}=5, \mathrm{H} \\
\text { ity, } \mathrm{L}=10, \mathrm{H}\end{array}$ & & & \\
\hline $\begin{array}{l}\text { Intangible } \\
\text { costs }(i)\end{array}$ & - & 0 & $c$ & & 0 & & o & \\
\hline $\begin{array}{l}\text { Hurdle rate } \\
\qquad(\boldsymbol{r})\end{array}$ & $\begin{array}{l}\text { Implicit in } \\
\text { LCOE (see } \\
\text { Table 4) }\end{array}$ & \multicolumn{7}{|c|}{$\begin{array}{c}\text { Social, } \mathrm{L}=3 \%, \mathrm{H}=6 \% \text {, for example [2] } \\
\text { Individual } \mathrm{L}=9 \%, \mathrm{H}=17 \% \text {, for example [3] }\end{array}$} \\
\hline $\begin{array}{l}\text { Retrofitting / } \\
\text { replacement } \\
\text { rate }(\boldsymbol{b})\end{array}$ & $\begin{array}{l}\text { Technology } \\
\text { specific, } \\
\text { based on }[4,5]\end{array}$ & $\begin{array}{l}\text { Every } 15 \\
\text { years }\end{array}$ & $\begin{array}{l}\text { Every } 15 \\
\text { years }\end{array}$ & $\begin{array}{l}\text { Every } 20 \\
\text { years }\end{array}$ & $\begin{array}{l}\text { Every } 10 \\
\text { years }\end{array}$ & & - & \\
\hline
\end{tabular}


The effect of adopting different values for the heterogeneity parameter, $\boldsymbol{v}$ are illustrated below with an example comparing two technologies against one another. As $\boldsymbol{v}$ approaches zero, the costs of different options play little to no role in investment choices (i.e. implying that non-monetary factors are the driver), while for high values of $\boldsymbol{v}$ the model displays highly cost optimising behaviour.

Figure 2 - Visualising the Impact of the Heterogeneity Parameter

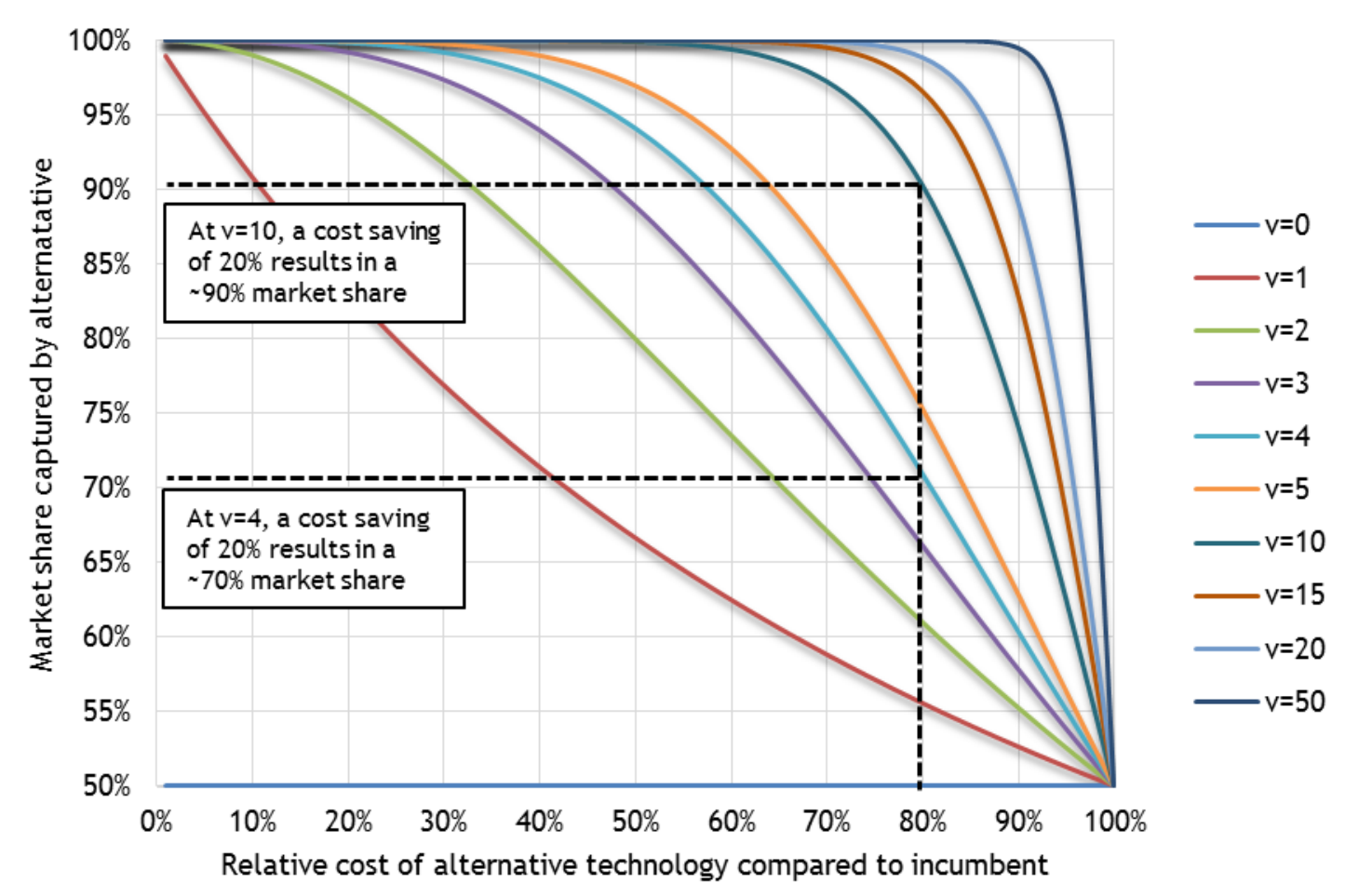

Table 2 - Qualitative ranges for defining actor heterogeneity

\begin{tabular}{|c|c|l|}
\hline Definition & $\boldsymbol{v}$ & \multicolumn{1}{c|}{ Description } \\
\hline $\begin{array}{c}\text { Cost optimising } \\
\text { behaviour }\end{array}$ & $20-50$ & $\begin{array}{l}\text { Actors will choose the least cost option almost every time, even if the savings are very } \\
\text { small. For example, at } \boldsymbol{v}=50, \text { a } 5 \% \text { saving results in a } 95 \% \text { uptake. }\end{array}$ \\
\hline $\begin{array}{c}\text { Strong price } \\
\text { sensitivity }\end{array}$ & $10-19$ & $\begin{array}{l}\text { In this range, actors react strongly to prices, but prices do not guide all their decisions. } \\
\text { For example, at } \boldsymbol{v}=15, \mathrm{~A}>30 \% \text { saving would be needed to drive replacement of the entire } \\
\text { capital stock with the lowest cost alternative. }\end{array}$ \\
\hline $\begin{array}{c}\text { Partial price } \\
\text { sensitivity }\end{array}$ & $5-9$ & $\begin{array}{l}\text { At this setting, actors are price conscious but often very large cost savings are required } \\
\text { before a total switch to new technologies occurs. For example, at } \boldsymbol{v}=5, \text { a }>70 \% \text { saving is } \\
\text { required for complete replacement. }\end{array}$ \\
\hline $\begin{array}{c}\text { Price insensitive } \\
\text { behaviour }\end{array}$ & $0-4$ & $\begin{array}{l}\text { With these inputs, actors do not react strongly to prices. Even large cost savings might } \\
\text { not cause a complete shift to the new technology. }\end{array}$ \\
\hline
\end{tabular}




\subsubsection{Energy Service Demands and Energy Prices}

Energy service demands are assumed to grow in line with user-defined exogenous drivers that are calibrated to reflect individual national circumstances. Energy service demands are affected by demand elasticity parameters and the rate of change in energy prices between $t=t$ and $t=1-1$. This is expressed as:

$D_{s, t}=D_{s, t-1} \times\left[1+G_{s}\right] \times\left[e_{s, t-1}\left(1-\Delta P_{s, t-1}\right)\right]$

Where $\boldsymbol{D}=$ energy service demand, $\boldsymbol{s}=$ sector, $\boldsymbol{t}=$ time period, $\boldsymbol{G}=$ demand driver, $\boldsymbol{P}=$ energy price, and $\boldsymbol{e}=$ price elasticity of demand.

Energy prices grow by a user input rate through time, which can be aligned with policy projections or randomised as desired by the user. Energy prices contain a fuel price component and a carbon price component.

$E_{f, t}=\left[P_{f, t-1} \times\left(1+k_{f}\right)\right]+\left[z_{f, t} \times\left\{C O_{2, t-1} \times(1+j)\right\}\right]$

Where $\boldsymbol{E}=$ energy price, $\boldsymbol{P}=$ fuel price, $\boldsymbol{t}=$ time period, $\boldsymbol{f}=$ fuel type, $\boldsymbol{k}=$ periodic fuel price increase/decrease, $\mathrm{CO}_{2}=$ carbon price $j=$ periodic carbon price increase/decrease and $\boldsymbol{z}=$ specific emissions intensity.

\subsubsection{Capital Stock Replacement}

Each sector evaluates the net present value of competing technology options. The net present value of available technologies is expressed as:

$N_{s, t, x}=C_{s, t, x}+i_{s, t, x}+\sum_{t}^{T}\left[\frac{D_{s, t} \times P_{f, t} \times Y_{s, t, x}^{-1}}{\left(1+r_{s, t}\right)^{t}}\right]$

Where $\boldsymbol{N}=$ net present value, $\boldsymbol{s}=$ sector, $\boldsymbol{t}=$ time period, $\boldsymbol{x}=$ energy technology, $\boldsymbol{C}=$ investment cost, $\boldsymbol{i}=$ intangible cost, $D=$ energy service demand, $f=$ fuel type, $Y=$ efficiency, $r=$ hurdle rate, $T$ =investment time horizon

The net present value then serves as an input into the model's evaluation of technology diffusion into the marketplace.

$M_{s, t, x}=\left[M_{s, t-1, x} \times\left(1-b_{s, t}\right)\right]+\left[M_{s, t-1} \times b_{s, t} \times\left(\frac{N_{s, t}^{-v_{s, t}}}{\sum_{x} N_{s, t}^{-v_{s, t}}}\right)\right]$

Where $\boldsymbol{M}=$ technology portfolio, $\boldsymbol{s}=$ sector $\boldsymbol{t}=$ time period, $\boldsymbol{x}=$ energy technology, $\boldsymbol{b}$ = retrofitting/replacement rate, $\boldsymbol{N}=$ net present value, $\boldsymbol{v}=$ heterogeneity parameter 


\subsubsection{Base Year Energy Service Demands}

The BLUE model is calibrated for the United Kingdom using official government statistics and a 2010 base year. Energy service demands originally given in other units are converted to petajoules (PJ).

Table 3-BLUE Base Year Calibration Data

\begin{tabular}{|l|c|c|c|l|}
\hline \multirow{3}{*}{ Parameter } & Sub-Parameter & $\begin{array}{c}\text { Value } \\
\text { (L=Low, C=Central, H=High) }\end{array}$ & Units & Notes \\
\hline & Residential & 2064 & & \\
Energy & Commercial & 821 & & \\
Service & Industrial & 1093 & PJ & UK Department of Energy and \\
Demands & Transport (Road) & 1691 & & \\
& Transport (Air) & 515 & & \\
& Transport (Rail) & 42 & & \\
& Transport (Marine) & 38 & & \\
\hline
\end{tabular}

\subsubsection{Fuel Costs and Emission Factors}

BLUE currently employs a stylised representation of fuel types. For example, various types of liquid transport fuels are aggregated together into "Oil", while different coal grades (e.g. bituminous coal, anthracite, etc.) are covered by "Coal". Electricity costs and emission intensities are determined dynamically based on the generation portfolio used in each time period (see below).

Table 4 - BLUE Fuel Costs and Emission Factors

\begin{tabular}{|c|c|c|c|c|}
\hline Parameter & Sub-Parameter & $\begin{array}{c}\text { Value } \\
\begin{array}{c}\text { (L=Low, C=Central, } \\
\mathrm{H}=\text { High) }\end{array}\end{array}$ & Units & Notes \\
\hline $\begin{array}{l}\text { Fossil Fuel } \\
\text { Prices }\end{array}$ & $\begin{array}{l}\text { Oil } \\
\text { Coal } \\
\text { Gas }\end{array}$ & $\begin{array}{l}\text { Dynamic } \\
\text { Dynamic } \\
\text { Dynamic }\end{array}$ & E/GJ & $\begin{array}{l}\text { Triangular distributions based on } \\
\text { projections from UK Department of } \\
\text { Energy and Climate Change (DECC) } \\
\text { [7]. }\end{array}$ \\
\hline $\begin{array}{l}\text { Fossil Fuel } \\
\text { Emission } \\
\text { Intensities }\end{array}$ & $\begin{array}{l}\text { Oil } \\
\text { Coal } \\
\text { Gas }\end{array}$ & $\begin{array}{l}0.0917 \\
0.0763 \\
0.0517\end{array}$ & $\mathrm{tCO}_{2} / \mathrm{GJ}$ & $\begin{array}{l}\text { US Energy Information } \\
\text { Administration (EIA) [8] }\end{array}$ \\
\hline
\end{tabular}

\subsubsection{Power Generation}

BLUE employs 9 different power technologies that characterise the base year generation fleet as well as capturing future options for electricity supply. The technoeconomic performance of different options is expressed in terms of their levelised 
costs of energy ( $L C O E$, see [9]), which is determined from unit estimates of capital costs, fixed operation and maintenance costs, and variable operation and maintenance costs taken from a range of government and academic sources (see below). BLUE's stylized representation of the power sector determines total generation requirements against a user defined capacity margin, while the contribution to total capacity requirements from individual technologies varies by technology.

Table 5 - Power Generation Parameters

\begin{tabular}{|c|c|c|c|c|}
\hline Parameter & Sub-Parameter & $\begin{array}{c}\text { Value } \\
(\mathrm{L}=\text { Low, } \mathrm{C}=\text { Central, } \mathrm{H}=\text { High) }\end{array}$ & Units & Notes \\
\hline $\begin{array}{l}\text { Power } \\
\text { Generation } \\
\text { Technology } \\
\text { Portfolio }\end{array}$ & $\begin{array}{c}\text { Gas } \\
\text { Coal } \\
\text { Coal-CCS } \\
\text { Gas-CCS } \\
\text { Nuclear } \\
\text { Onshore Wind } \\
\text { Offshore Wind } \\
\text { Large Scale Solar PV } \\
\text { Bioenergy-CCS }\end{array}$ & $\begin{array}{c}35 \cdot 3 \\
35 \cdot 8 \\
0 \\
0 \\
10.9 \\
0 \\
4.218 \\
0 \\
0\end{array}$ & GW & $\begin{array}{l}\text { UK Department of Energy and } \\
\text { Climate Change [10]. }\end{array}$ \\
\hline $\begin{array}{l}\text { Power } \\
\text { Generation } \\
\text { Technology } \\
\text { Capital Costs }\end{array}$ & $\begin{array}{c}\text { Gas } \\
\text { Coal } \\
\text { Coal-CCS } \\
\text { Gas-CCS } \\
\text { Nuclear } \\
\text { Onshore Wind } \\
\text { Offshore Wind } \\
\text { Large Scale Solar PV } \\
\text { Bioenergy-CCS }\end{array}$ & $\begin{array}{r}L=601, C=669, H=805 \\
L=1488, C=1648, H=1865 \\
L=3387, C=3584, H=3856 \\
L=1462, C=1634, H=1888 \\
L=5082, H=5767 \\
L=1221, C=1532, H=1910 \\
L=2046, C=2685, H=3650 \\
\quad L=1038, H=1140 \\
L=2433, C=4055, H=5677\end{array}$ & $\mathrm{f} / \mathrm{kW}$ & $\begin{array}{l}\text { Triangular distributions used where } \\
\text { literature provides low }(\mathrm{L}) \text {, central } \\
(\mathrm{C}) \text { and high }(\mathrm{H}) \text { values, uniform } \\
\text { distributions used for high / low } \\
\text { data. } \\
\text { Sources include a range of } \\
\text { government and academic } \\
\text { references converted to } 2010 \text { base } \\
\text { year }[4,5,11,12]\end{array}$ \\
\hline $\begin{array}{l}\text { Power } \\
\text { Generation } \\
\text { Technology } \\
\text { Fixed } \\
\text { Operating } \\
\text { Costs (FOM) }\end{array}$ & $\begin{array}{c}\text { Gas } \\
\text { Coal } \\
\text { Coal-CCS } \\
\text { Gas-CCS } \\
\text { Nuclear } \\
\text { Onshore Wind } \\
\text { Offshore Wind } \\
\text { Large Scale Solar PV } \\
\text { Bioenergy-CCS }\end{array}$ & $\begin{array}{c}L=14.7, C=27.4, H=40.3 \\
L=15 \cdot 4, C=42.6, H=66.4 \\
L=39 \cdot 3, C=81.0, H=120.0 \\
L=26.4, C=45 \cdot 5, H=67.7 \\
L=65.5, C=87.2, H=110.0 \\
C=15.0 \\
L=63.0, H=71.0 \\
L=24.0, H=27.0 \\
L=96.0, C=96.0, H=96.0\end{array}$ & $\begin{array}{l}\text { f/kWh/ } \\
\text { year }\end{array}$ & $\begin{array}{l}\text { Triangular distributions used where } \\
\text { literature provides low }(L) \text {, central } \\
\text { (C) and high }(H) \text { values, uniform } \\
\text { distributions used for high / low } \\
\text { data. } \\
\text { Sources include a range of } \\
\text { government and academic } \\
\text { references converted to } 2010 \text { base } \\
\text { year }[4,5,11,12]\end{array}$ \\
\hline $\begin{array}{l}\text { Power } \\
\text { Generation } \\
\text { Technology } \\
\text { Variable } \\
\text { Operating } \\
\text { Costs (VOM) }\end{array}$ & $\begin{array}{c}\text { Gas } \\
\text { Coal } \\
\text { Coal-CCS } \\
\text { Gas-CCS } \\
\text { Nuclear } \\
\text { Onshore Wind } \\
\text { Offshore Wind } \\
\text { Large Scale Solar PV }\end{array}$ & $\begin{array}{c}L=0, C=0.0001, H=0.0002 \\
L=0.0008, C=0.001, H=0.0012 \\
L=0.0093, C=0.0103, H=0.0113 \\
L=0.0035, C=0.0044, H=0.0053 \\
C=0.0285 \\
C=0.003 \\
C=0.0015 \\
0\end{array}$ & $\begin{array}{l}\text { f/kWh/ } \\
\text { year }\end{array}$ & $\begin{array}{l}\text { Triangular distributions used where } \\
\text { literature provides low }(L) \text {, central } \\
\text { (C) and high }(H) \text { values, uniform } \\
\text { distributions used for high / low } \\
\text { data. } \\
\text { Sources include a range of } \\
\text { government and academic } \\
\text { references converted to } 2010 \text { base } \\
\text { year }[4,5,11,12] \text {. For some }\end{array}$ \\
\hline
\end{tabular}




\begin{tabular}{|c|c|c|c|c|}
\hline & Bioenergy-CCS & $L=0.012, C=0.024, H=0.036$ & & $\begin{array}{l}\text { technologies sources VOM costs in } \\
\text { FOM values. }\end{array}$ \\
\hline $\begin{array}{l}\text { Power } \\
\text { Generation } \\
\text { Technology } \\
\text { Thermal } \\
\text { Efficiency }\end{array}$ & $\begin{array}{c}\text { Gas } \\
\text { Coal } \\
\text { Coal-CCS } \\
\text { Gas-CCS } \\
\text { Nuclear } \\
\text { Onshore Wind } \\
\text { Offshore Wind } \\
\text { Large Scale Solar PV } \\
\text { Bioenergy-CCS }\end{array}$ & $\begin{aligned} L=57, C & =58, H=60 \\
L= & 43, C=44, H=45 \\
L=35.8, C & =36.7, H=37.5 \\
L=47.5, C & =48.3, H=50 \\
- & - \\
- & - \\
L=25, C= & 26.1, H=27.2\end{aligned}$ & $\%$ & $\begin{array}{l}\text { Triangular distributions used where } \\
\text { literature provides low }(\mathrm{L}) \text {, central } \\
(\mathrm{C}) \text { and high }(\mathrm{H}) \text { values, uniform } \\
\text { distributions used for high / low } \\
\text { data. } \\
\text { Sources include a range of } \\
\text { government and academic } \\
\text { references converted to } 2010 \text { base } \\
\text { year }[4,5,11,12] \text {. }\end{array}$ \\
\hline $\begin{array}{l}\text { Power } \\
\text { Generation } \\
\text { Technology } \\
\text { Deployment } \\
\text { Constraints }\end{array}$ & $\begin{array}{c}\text { Gas } \\
\text { Coal } \\
\text { Coal-CCS } \\
\text { Gas-CCS } \\
\text { Nuclear } \\
\text { Onshore Wind } \\
\text { Offshore Wind } \\
\text { Large Scale Solar PV } \\
\text { Bioenergy-CCS }\end{array}$ & $\begin{array}{l}- \\
- \\
- \\
- \\
40 \\
20 \\
60 \\
20 \\
17\end{array}$ & GW & $\begin{array}{l}\text { Nuclear constraint based on build } \\
\text { rate assumptions for model time } \\
\text { horizon. } \\
\text { Wind power constraints based on } \\
\text { reports commissioned by } \\
\text { government }[13] \text { and by industry } \\
\text { [14]. } \\
\text { Bioenergy constraint is consistent } \\
\text { with not exceeding resource limits } \\
\text { implied by CCC Bioenergy Review } \\
\text { Further Land Conversion (FLC) } \\
\text { scenario }[15,16] \text {. }\end{array}$ \\
\hline $\begin{array}{l}\text { Transmission } \\
\text { and } \\
\text { Distribution } \\
\text { Losses }\end{array}$ & - & 7.9 & $\%$ & $\begin{array}{l}\text { UK Digest of United Kingdom } \\
\text { Energy Statistics [10] }\end{array}$ \\
\hline $\begin{array}{l}\text { Capacity } \\
\text { Margin }\end{array}$ & - & 20 & $\%$ & $\begin{array}{l}\text { Based on Royal Academy of } \\
\text { Engineering [17] }\end{array}$ \\
\hline $\begin{array}{l}\text { Power } \\
\text { Generation } \\
\text { Technology } \\
\text { De-Rating } \\
\text { Factors }\end{array}$ & $\begin{array}{c}\text { Gas } \\
\text { Coal } \\
\text { Coal-CCS } \\
\text { Gas-CCS } \\
\text { Nuclear } \\
\text { Onshore Wind } \\
\text { Offshore Wind } \\
\text { Large Scale Solar PV } \\
\text { Bioenergy-CCS }\end{array}$ & $\begin{array}{c}0.88 \\
0.85 \\
0.88 \\
0.85 \\
0.81 \\
\mathrm{~L}=0.17, \mathrm{H}=0.24 \\
\mathrm{~L}=0.17, \mathrm{H}=0.24 \\
0 \\
0.88\end{array}$ & $\%$ & $\begin{array}{l}\text { Based on Ofgem generator de-rating } \\
\text { factors by technology type [18] } \\
\text { Note we conservatively assume that } \\
\text { Solar PV does not contribute to } \\
\text { meeting UK peak capacity } \\
\text { requirements. }\end{array}$ \\
\hline
\end{tabular}




\subsubsection{Building Sectors}

BLUE currently features 3 types of building heating technology. Disaggregation of energy demands into heat and electricity is based on UK government statistics for the residential [19] and commercial sectors [20].

Table 6 - Building Sector Parameters

\begin{tabular}{|c|c|c|c|c|}
\hline Parameter & Sub-Parameter & $\begin{array}{c}\text { Value } \\
\text { (L=Low, } C=\text { Central, } \mathrm{H}=\text { High) }\end{array}$ & Units & Notes \\
\hline $\begin{array}{l}\text { Residential } \\
\text { Heating } \\
\text { Technology } \\
\text { Portfolio }\end{array}$ & $\begin{array}{l}\text { Gas Boiler } \\
\text { Elec. Resistive Heating } \\
\text { Air Source Heat Pump }\end{array}$ & $\begin{array}{c}92.8 \\
7.2 \\
0\end{array}$ & $\%$ & $\begin{array}{l}\text { UK Department of Energy and } \\
\text { Climate Change (DECC) [6]. }\end{array}$ \\
\hline $\begin{array}{l}\text { Residential } \\
\text { Heating } \\
\text { Technology } \\
\text { Costs }\end{array}$ & $\begin{array}{l}\text { Gas Boilers } \\
\text { Elec. Resistive Heating } \\
\text { Air Source Heat Pumps }\end{array}$ & $\begin{array}{c}L=2500, H=3000 \\
L=1750, H=4025 \\
L=8400, H=10500\end{array}$ & $£$ & $\begin{array}{l}\text { Uniform distributions used to span } \\
\text { range of estimates [21]. }\end{array}$ \\
\hline $\begin{array}{l}\text { Residential } \\
\text { Heating } \\
\text { Efficiency }\end{array}$ & $\begin{array}{l}\text { Gas Boilers } \\
\text { Elec. Resistive Heating } \\
\text { Air Source Heat Pumps }\end{array}$ & $\begin{array}{c}94 \\
100 \\
250-275\end{array}$ & $\%$ & Based on NERA and AEA [21] \\
\hline $\begin{array}{l}\text { Commercial } \\
\text { Heating } \\
\text { Technology } \\
\text { Portfolio }\end{array}$ & $\begin{array}{l}\text { Gas Boilers } \\
\text { Elec. Resistive Heating } \\
\text { Air Source Heat Pumps }\end{array}$ & $\begin{array}{c}87 \\
13 \\
0\end{array}$ & $\%$ & $\begin{array}{l}\text { Based on UK Department of Energy } \\
\text { and Climate Change [20] }\end{array}$ \\
\hline $\begin{array}{l}\text { Commercial } \\
\text { Heating } \\
\text { Technology } \\
\text { Costs }\end{array}$ & $\begin{array}{l}\text { Gas Boilers } \\
\text { Elec. Resistive Heating } \\
\text { Air Source Heat Pumps }\end{array}$ & $\begin{array}{l}18142 \\
42653 \\
29975\end{array}$ & $£$ & $\begin{array}{l}\text { Based on NERA and AEA [21]. } \\
\text { Report only gives a single value for } \\
\text { representative heat pump } \\
\text { installation so no ranges used }\end{array}$ \\
\hline $\begin{array}{l}\text { Commercial } \\
\text { Heating } \\
\text { Efficiency }\end{array}$ & $\begin{array}{l}\text { Gas Boilers } \\
\text { Elec. Resistive Heating } \\
\text { Air Source Heat Pumps }\end{array}$ & $\begin{array}{c}94 \\
100 \\
350\end{array}$ & $\%$ & Based on NERA and AEA [21] \\
\hline
\end{tabular}

\subsubsection{Industrial Sector}

The industrial sector in BLUE employs a stylized representation that allows fuel switching on a cost basis, but does not capture the details of individual industrial processes.

Table 7 - Industrial Sector Parameters

\begin{tabular}{|l|r|r|r|r|}
\hline Parameter & Sub-Parameter & Value & Notes \\
& & Units & Low, C=Central, H=High $)$ & \\
\hline
\end{tabular}




\begin{tabular}{|l|c|l|l|l|}
\hline Industrial & Coal & 0.088 & & \\
Fuel & Oil & 0.210 & $\%$ & Based on UK Department of Energy \\
Portfolio & Gas & 0.357 & & \\
& Electricity & 0.344 & & \\
\hline
\end{tabular}

\subsubsection{Road Transport Sector}

BLUE currently features 2 types of road vehicle technology - a generic electric drivetrain vehicle and a generic fossil fuel vehicle.

Table 8 - Road Transport Sector Parameters

\begin{tabular}{|c|c|c|c|c|}
\hline Parameter & Sub-Parameter & $\begin{array}{c}\text { Value } \\
\text { (L=Low, } C=\text { Central, } \mathrm{H}=\text { High) }\end{array}$ & Units & Notes \\
\hline $\begin{array}{l}\text { Road } \\
\text { Transport } \\
\text { Technology } \\
\text { Portfolio }\end{array}$ & $\begin{array}{c}\text { Fossil Fuel Vehicles } \\
\text { Electric Vehicles }\end{array}$ & $\begin{array}{c}100 \\
0\end{array}$ & $\%$ & $\begin{array}{l}\text { Electric vehicle sales in the UK were } \\
\text { less than } 0.1 \% \text { of annual sales in } \\
2012[23] \text {, so it can be assumed that } \\
\text { as a fraction of the road fleet } \\
\text { composition they were negligible in } \\
2010 \text {. }\end{array}$ \\
\hline $\begin{array}{l}\text { Road } \\
\text { Transport } \\
\text { Technology } \\
\text { Costs }\end{array}$ & $\begin{array}{c}\text { Fossil Fuel Vehicles } \\
\text { Electric Vehicles }\end{array}$ & $\begin{array}{c}14330 \\
L=25620, C=20490, H=59440\end{array}$ & $£$ & $\begin{array}{l}\text { Representative values for C/D class } \\
\text { vehicles, based on [24]. }\end{array}$ \\
\hline $\begin{array}{l}\text { Road } \\
\text { Transport } \\
\text { Efficiency }\end{array}$ & $\begin{array}{c}\text { Fossil Fuel Vehicles } \\
\text { Electric Vehicles }\end{array}$ & $\begin{array}{c}L=2500, H=3000 \\
1389\end{array}$ & $\mathrm{~km} / \mathrm{GJ}$ & $\begin{array}{l}\text { Fossil vehicle range based on UK } \\
\text { Department for Transport [25], with } \\
\text { electric vehicle value based on } \\
\text { International Energy Agency [26] }\end{array}$ \\
\hline
\end{tabular}

\subsubsection{Other Transport Sectors}

The non-road transport sectors have few technological mitigation options in the current model version. Future changes to aviation technologies are captured as reductions in $\mathrm{CO}_{2}$ intensity per unit of energy demand to reflect efficiency improvements that are likely to arise over the time horizon at zero marginal costs from existing R\&D investments [27]. Radical design changes to aircraft and/or air travel infrastructure are not represented. Fuel switching and technological change in the marine and rail sectors is also not presently captured in the current model version. These latter two sectors are currently small in absolute consumption terms, together comprising $3.5 \%$ of UK transport energy demand [6].

\subsection{Appendix References}

[1] S. Pye, W. Usher, N. Strachan, The uncertain but critical role of demand reduction in meeting long-term energy decarbonisation targets, Energy Policy. 73 (2014) 575-586. doi:10.1016/j.enpol.2014.05.025. 
[2] A.H. Hermelink, D. de Jager, Evaluating our Future: The Crucial Role of Discount Rates in European Commission Energy System Modelling, Ecofys for The European Council for an Energy Efficient Economy (eceee), 2015. http://europeanclimate.org/evaluating-our-future-the-crucial-role-of-discountrates-in-european-commission-energy-system-modelling/.

[3] Oxera Consulting Ltd, Discount Rates for Low-Carbon and Renewable Generation Technologies: Prepared for the Committee on Climate Change, Oxford, UK, 2011.

[4] Parsons Brinckerhoff, Electricity Generation Cost Model - 2011 Update, 2011. http://www.decc.gov.uk/assets/decc/11/meeting-energydemand/nuclear/2153-electricity-generation-cost-model-2011.pdf.

[5] Parsons Brinckerhoff, Electricity Generation Costs Model: 2013 Update of Renewable Technologies, Parsons Brinckerhoff, Newcastle, UK, 2013. https://www.gov.uk/government/publications/parsons-brinkerhoff-electricitygeneration-model-2013-update-of-renewable-technologies.

[6] DECC, Energy consumption in the United Kingdom: 2011 - Overall energy consumption in the UK since 1970 (Publication URN 11D/806), UK Department of Energy and Climate Change (DECC), London, UK, 2011.

[7] DECC, DECC Fossil Fuel Price Projections, July 2013 (URN 13D/170), Department of Energy and Climate Change (DECC), London, UK, 2013. https://www.gov.uk/government/uploads/system/uploads/attachment_data/fil e/212521/130718_decc-fossil-fuel-price-projections.pdf.

[8] ElA, Annual Energy Review 2011: DOE/EIA-0384(2011), United States Energy Information Administration (EIA), Washington D.C., USA, 2012. https://www.eia.gov/totalenergy/data/annual/pdf/aer.pdf.

[9] E. de Visser, A. Held, Methodologies for estimating Levelised Cost of Electricity (LCOE), 2014. http://res-cooperation.eu/images/pdf-

reports/ECOFYS_Fraunhofer_Methodologies_for_estimating_LCoE_Final_rep ort.pdf.

[10] DECC, Digest of United Kingdom Energy Statistics (DUKES) 2015, Department of Energy and Climate Change (DECC), London, UK, 2015. https://www.gov.uk/government/statistics/digest-of-united-kingdom-energystatistics-dukes-2015-printed-version.

[11] G. Harris, P. Heptonstall, R. Gross, D. Handley, Cost estimates for nuclear power in the UK, ICEPT Working Paper (ICEPT/WP/2012/014), Imperial College Centre for Energy Policy and Technology (ICEPT), London, UK, 2012. https://workspace.imperial.ac.uk/icept/Public/Cost.

[12] DECC, Renewables Obligation Banding Review for the period 1 April 2013 to 31 March 2017: Government Response to further consultations on solar PV support, biomass affordability and retaining the minimum calorific value requirement in the $\mathrm{RO}, 2012$.

https://www.gov.uk/government/uploads/system/uploads/attachment_data/fil e/66516/7328-renewables-obligation-banding-review-for-the-perio.pdf. 
[13] SKM, Quantification of Constraints on the Growth of UK Renewable Generating Capacity, Sinclair Knight Merz (SKM), Newcastle upon Tyne, UK, 2008.

https://www.gov.uk/government/uploads/system/uploads/attachment_data/fil e/42966/1_20090501131320_e___SKMRenewableConstraintsReportFinal4250 62008.pdf.

[14] The Offshore Valuation Group, The Offshore Valuation, Department of Energy \& Climate Change, Scottish Government, Welsh Assembly Government, Crown Estate, Energy Technologies Institute, Scottish \& Southern Energy, RWE Innogy, E.ON, DONG Energy, Statoil, Mainstream Renewable Power, RES, Vestas, PIRC, 2010. http://publicinterest.org.uk/offshore/.

[15] CCC, Bioenergy Review, The Committee on Climate Change (CCC), London, UK, 2011. http://www.theccc.org.uk/reports/bioenergy-review.

[16] CCC, Bioenergy Review: Technical Paper 2: Global and UK Bioenergy Supply Scenarios, The Committee on Climate Change (CCC), London, UK, 2011. http://archive.theccc.org.uk/aws2/Bioenergy/1463.

[17] Royal Academy of Engineering, GB electricity capacity margin, The Royal Academy of Engineering, London, UK, 2013.

https://www.gov.uk/government/publications/electricity-capacity-marginreport.

[18] Ofgem, Electricity Capacity Asessment Report 2013, Office of Gas and Electricity Markets (Ofgem), London, UK, 2013.

https://www.ofgem.gov.uk/ofgem-publications/75232/electricity-capacityassessment-report-2013.pdf.

[19] DECC, Energy consumption in the United Kingdom (2015): Chapter 3 Domestic energy consumption in the UK between 1970 and 2014 (Publication URN 15D/377), Department of Energy and Climate Change (DECC), London, UK, 2015. https://www.gov.uk/government/statistics/energy-consumption-inthe-uk.

[20] DECC, Energy consumption in the United Kingdom (2015): Chapter 5 - Service sector energy consumption in the UK between 1970 and 2014 (Publication URN 15D/381), Department of Energy and Climate Change (DECC), London, UK, 2015. https://www.gov.uk/government/statistics/energy-consumption-in-theuk.

[21] NERA, AEA, The UK Supply Curve for Renewable Heat: Study for the Department of Energy and Climate Change, Department of Energy and Climate Change (DECC), London, UK, 2009.

http://www.rhincentive.co.uk/library/regulation/ogo7Heat_Supply_Curve.pdf.

[22] DECC, Energy consumption in the United Kingdom (2015): Chapter 4 Industrial energy consumption in the UK between 1970 and 2014 (Publication URN 15D/379), Department of Energy and Climate Change (DECC), London, UK, 2015. https://www.gov.uk/government/statistics/energy-consumption-inthe-uk. 
[23] Element Energy, Pathways to high penetration of electric vehicles: Final report for the Committee on Climate Change, Element Energy, Cambridge, UK, 2013. http://www.theccc.org.uk/wp-content/uploads/2013/12/CCC-EVpathways_FINAL-REPORT_17-12-13-Final.pdf.

[24] Element Energy, Influences on the Low Carbon Car Market from 2020-2030: Final Report for Low Carbon Vehicle Partnership, Element Energy, Cambridge, UK, 2011. lowcvp.org.uk/assets/reports/Influences.

[25] DfT, Average new car fuel consumption: Great Britain (Table ENV0103), UK Department for Transport (DfT), London, UK, 2014. https://www.gov.uk/government/statistical-data-sets/envo1-fuelconsumption.

[26] IEA, Technology Roadmap: Electric and plug-in hybrid electric vehicles, International Energy Agency (IEA), Paris, France, 2011.

https://www.iea.org/publications/freepublications/publication/EV_PHEV_Road map.pdf.

[27] A.W. Schäfer, A.D. Evans, T.G. Reynolds, L. Dray, Costs of mitigating $\mathrm{CO}_{2}$ emissions from passenger aircraft, Nat. Clim. Chang. 6 (2015) 412-417. doi:10.1038/nclimate2865. 